Photoperiodism in Relation to Hormones as Factors in Floral Initiation and Development Author(s): Karl C. Hamner and James Bonner

Source: Botanical Gazette, Vol. 100, No. 2 (Dec., 1938), pp. 388-431

Published by: The University of Chicago Press

Stable URL: https://www.jstor.org/stable/2471641

Accessed: 10-04-2020 15:40 UTC

JSTOR is a not-for-profit service that helps scholars, researchers, and students discover, use, and build upon a wide range of content in a trusted digital archive. We use information technology and tools to increase productivity and facilitate new forms of scholarship. For more information about JSTOR, please contact support@jstor.org.

Your use of the JSTOR archive indicates your acceptance of the Terms \& Conditions of Use, available at https://about.jstor.org/terms

The University of Chicago Press is collaborating with JSTOR to digitize, preserve and extend access to Botanical Gazette 


\section{PHOTOPERIODISM IN RELATION TO HORMONES AS FACTORS IN FLORAL INITIATION AND DEVELOPMENT ${ }^{\mathrm{I}}$}

CONTRIBUTIONS FROM THE HULL BOTANICAL LABORATORY 496

KARL C. HAMNER AND JAMES BONNER

(WITH ELEVEN FIGURES)

\section{Introduction}

In I925, GaRner and Allard (7) showed that, for some plants, the response to photoperiod is localized; that is, the separate portions of the plant directly subjected to the various photoperiods responded individually rather than there being a general systemic response of the entire plant. KNOTT (Io) demonstrated in 1934 that the initial effect of photoperiod is received by the leaves in spinach, a long day plant. Subsequently, workers in Russia, Cajlachjan (2), Moskov (16), Lubimenko (13), and others, extended the work of KNotr to other plants and confirmed his view that the leaves are the organs which receive the initial photoperiodic stimulus. Extensive studies of the movement of the effect within the plant and across graft unions have also been made. This work has recently been summarized by CaJLaChJaN (5).

Following the subjection of plants to photoperiods conducive to flowering, there seem to be produced certain effects which are capable of being transported within the plant, and across graft unions. The hypothesis has been advanced by CAJLACHJAN and others $(3, \mathrm{II}, \mathrm{I2}, \mathrm{I6})$ that a specific flower forming hormone is manufactured by leaves under certain photoperiods, and that this may move to various parts, resulting in floral initiation and often in subsequent development. SACHS (I7) suggested that specific flower forming substances probably exist. His experiments also indicated that such a substance must be supplied from the leaves. It remains

I This investigation was aided in part by a grant to the University of Chicago from the Rockefeller Foundation.

Botanical Gazette, vol. I0o] 
to be established that the flowering response is actually controlled by a specific chemical substance.

It is desirable to bear in mind precisely what is meant by the term "flowering condition" of plants (9). This term may be divided into at least six stages: (I) induction of the flowering condition; (2) initiation of the flower primordia; (3) development of these primordia into macroscopic flowers; (4) development of the fruit; (5) gametic union; and (6) development of seeds. There may well be many hormones which influence the flowering of plants, and not only may each particular hormone be involved in a single stage of the process, but there may be many interactions as well. The present work is concerned mainly with a study of the conditions leading to the induction and initiation of flower primordia, and their possible subsequent development.

Xanthium pennsylvanicum, a cocklebur, was chosen as the principal experimental material. If grown continuously under ordinary greenhouse conditions at photoperiods in excess of 16 hours, it remains vegetative indefinitely. It is a short day plant, possesses a sharp critical period, and blooms at photoperiods shorter than I 5 hours. Its floral primordia are readily recognizable under the dissecting microscope within 5 days after transfer of plants from long to short photoperiod. It possesses the advantage also that once floral primordia have been initiated under short photoperiods, they develop into flowers and fruits despite subsequent wide variations in environmental conditions. Xanthium grows rapidly, and if subjected to short photoperiods will flower in I4 days after emergence of the cotyledons from the soil.

\section{Terminology and experimental methods}

For the experiments reported here mature fruits of Xanthium pennsylvanicum were collected in November, and others which had passed the winter out of doors were collected in the vicinity of Chicago in early May. All were stored at room temperature in a dry place until used. The seeds were removed from the fruit, scratched slightly to rupture the seed coats, and after removal from the bur were planted within a few days in an open garden soil. Four seeds were sown in 4.5 inch pots, or roo seeds in an ordinary greenhouse 
flat. After the seedlings had attained a height of 6-10 inches, they were transplanted singly to 3.5 inch pots in order to obtain sturdy plants.

In certain experiments (section $\mathbf{X}$ ) the seeds were planted in pure quartz sand contained in 2 gallon glazed crocks, and supplied on alternate days with 500 cc. of SHIVE's slightly modified $R_{2} S_{5}$ nutrient solution (18). On intervening days the plants were supplied with distilled water. Such accessory growth factors as were used were

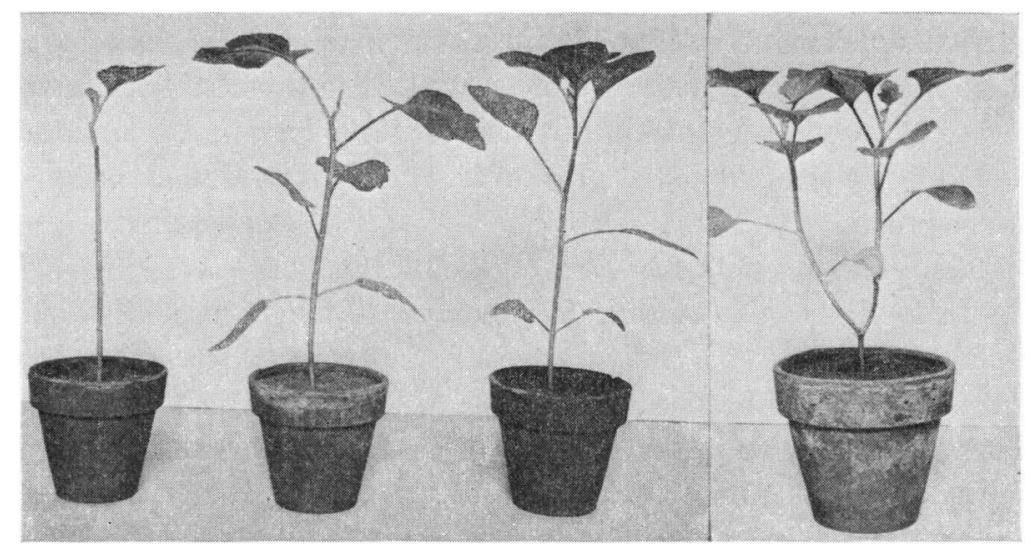

Fig. 1.-Plants at stage of development used in most experiments. From left to right: defoliated at base, defoliated at tip, intact (not defoliated), and two branched.

added to the nutrient solution just prior to its application to the crock.

Excessively high temperatures or low humidities were minimized by ventilation of the greenhouse and frequent spraying of the walks and benches. The plants were well watered and grew vigorously throughout the experimental period. In most of the experiments (those labeled higher than $\mathrm{X}-\mathrm{I}_{3}$ ) the plants were 3-5 weeks old. The plants used in experiments labeled $\mathrm{X}-\mathrm{I}$ to $\mathrm{X}-\mathrm{I} 3$, however, were more than 6 weeks old when used, and in all experiments concerned with two branched plants, the plants were $4^{-6}$ weeks old (fig. I). All plants were grown until used for experimentation on evenly lighted benches in the greenhouse. The natural daylight was supplemented with Mazda light of about roo foot candles at the surface 
of the leaves. These lights were burned from 7 P.M. until midnight in all experiments up to August I 7 , and from 6 P.M. until 2 A.M. after August I8. The photoperiod thus varied from I8.5 to 20.5 hours. Plants maintained continuously under these conditions of long photoperiod remained strictly vegetative. The term long photoperiod, as used in these experiments, means one in excess of 18.5 hours accompanied by a dark period of less than 5.5 hours. The term short photoperiod, as used in this work, refers to a photoperiod of 9 hours' duration with an accompanying dark period of 15 hours.

Great care was taken to maintain accurately the desired photoperiod. Lamps were checked daily, and plants were dissected periodically to make certain that they were in fact strictly vegetative. As a result of this checking, several thousand plants were discarded because of the accidental failure of the supplementary illumination for two nights. In every experiment also, control plants were dissected at the beginning and at the end of the experimental period. No experiment is reported in which control plants on long photoperiod or on 16 hour photoperiod were not strictly vegetative. With few exceptions, as noted in the tables, the plants subjected to a specific treatment exhibited a uniform response; that is, either all plants were strictly vegetative, or all plants possessed floral primordia or flowers at the same stage of development.

When it was desired to control accurately the photoperiod to which a group of plants was subjected, special trucks were used. During the day, in general for 9 hours, these trucks stood in an evenly lighted greenhouse. Each evening each truck was rolled into its light-tight compartment, where it remained until the following morning. In this way the plants received 9 hours of natural daylight, supplemented with artificial light of any desired duration from Mazda lamps controlled by time clocks. A series of smaller and simpler compartments were also used (fig. 2). Each evening the frames of these compartments were covered with black sateen cloth, two layers thick. These covers were removed each morning at 8 A.M. This set of seven compartments, each on a separate time clock, proved particularly useful for experiments in which it was desired to grow a few plants on each of a number of different photo- 
periods; that is, for determination of critical period, for interruption of the dark period by short light periods, etc.

In the experiments in which vegetative plants were grown as close to the critical day length as possible, the 9 hours of natural daylight were supplemented by light from Mazda lamps for 7 hours, thus making a total of 16 hours, a photoperiod just in excess of the critical $^{2}$ (section IV). This supplementary light was given immediately after the 9 hours of daylight on certain trucks, on others it was given immediately before. These two types of 16 hour photoperiods

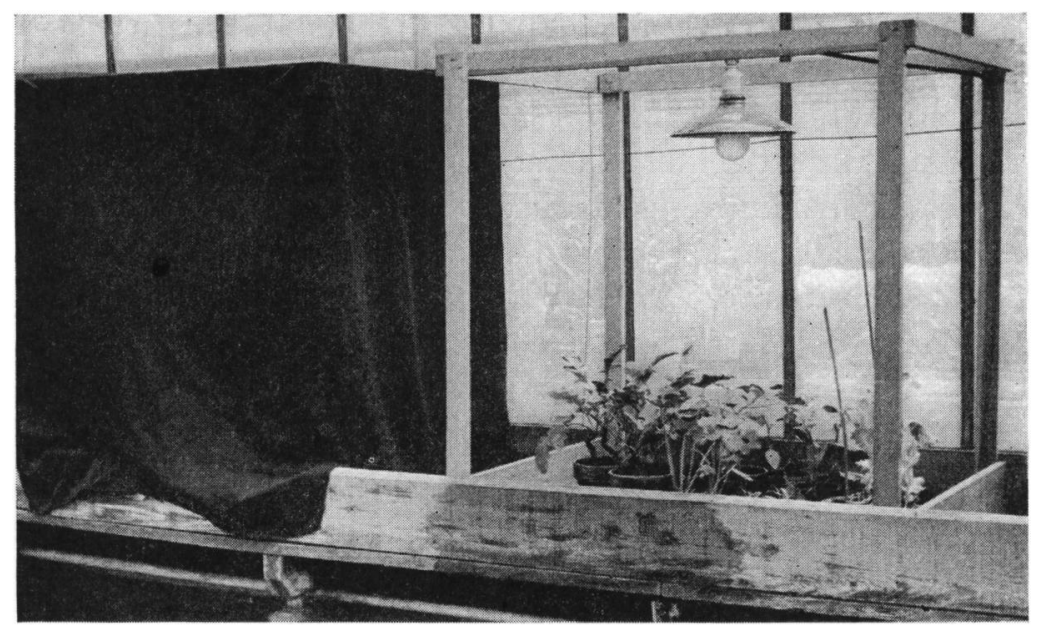

Fig. 2.-Type of small compartments used in experiments. The one at left has cover in place. Each controlled by separate time clock.

were used in the experiments of section IV. Plants which had been growing on a truck receiving supplementary light in the evening were removed during the day and placed on a truck receiving supplementary light in the early morning. These transferred plants then received a short photoperiod of 9 hours. The following dark period, however, was for them of 8 hours' duration. In this way the plants growing continuously on 16 hour photoperiods were given one short photoperiod without an accompanying long dark period.

${ }^{2}$ In some experiments, noted in the tables, a 15.5 hour day was used. In these experiments the controls were vegetative ( 15.5 hours was above the critical period). 
A standard, relatively simple procedure was developed for treating one portion of a plant with short photoperiod and the rest of the plant with long photoperiod. Cardboard cans were painted inside with flat black and outside with aluminum paint. The covers of the cans were removed, slit, and provided with a central hole (fig. 3). The covers were then slipped in an inverted position on to the stem of the plant, the stem passing through the central hole. The radial slit was then sealed with adhesive tape and the cover fastened firmly with thumbtacks to a wooden frame, to which the pot was also wired (fig. 3). The body of the can could then be inverted over the plant and slipped into position in the cover. The light intensity inside such a can is less than o.or foot candle even in bright sunlight, and the temperature was never more than $2^{\circ} \mathrm{F}$. above the temperature of the surrounding greenhouse air.

With this apparatus it was possible to obtain any combination of long and short photoperiod on different parts of the same plant. It was easy to assemble, and as many as $25^{\circ}$ cans have been placed in position night and morning by two people, the entire process consuming about 30 minutes.

In section IV experiments are described in which plants were submitted to various night temperatures. These plants were kept in the greenhouse during their photoperiod, and then transported for the dark period to darkrooms or compartments maintained at the required temperatures. Each morning the plants were returned to the greenhouse.

In the experiment in which a temperature of $4^{\circ} \mathrm{C}$. was maintained during the photoperiod, a room equipped with a cooling unit was used. This room was equipped with a carbon arc light, supplying about 900 foot candles at the leaf surface. A similar room kept at $2 \mathrm{I}^{\circ} \mathrm{C}$., illuminated with a carbon arc light for 10 hours per day and Mazda light for an additional 6 hours, was used for many of the experiments with cuttings as described in section $\mathrm{X}$.

By a vegetative plant is meant a plant which does not possess either flowers or recognizable floral primordia, and which, if maintained continuously on long photoperiod, does not develop them. The possession of one or more flowers or floral primordia is con- 

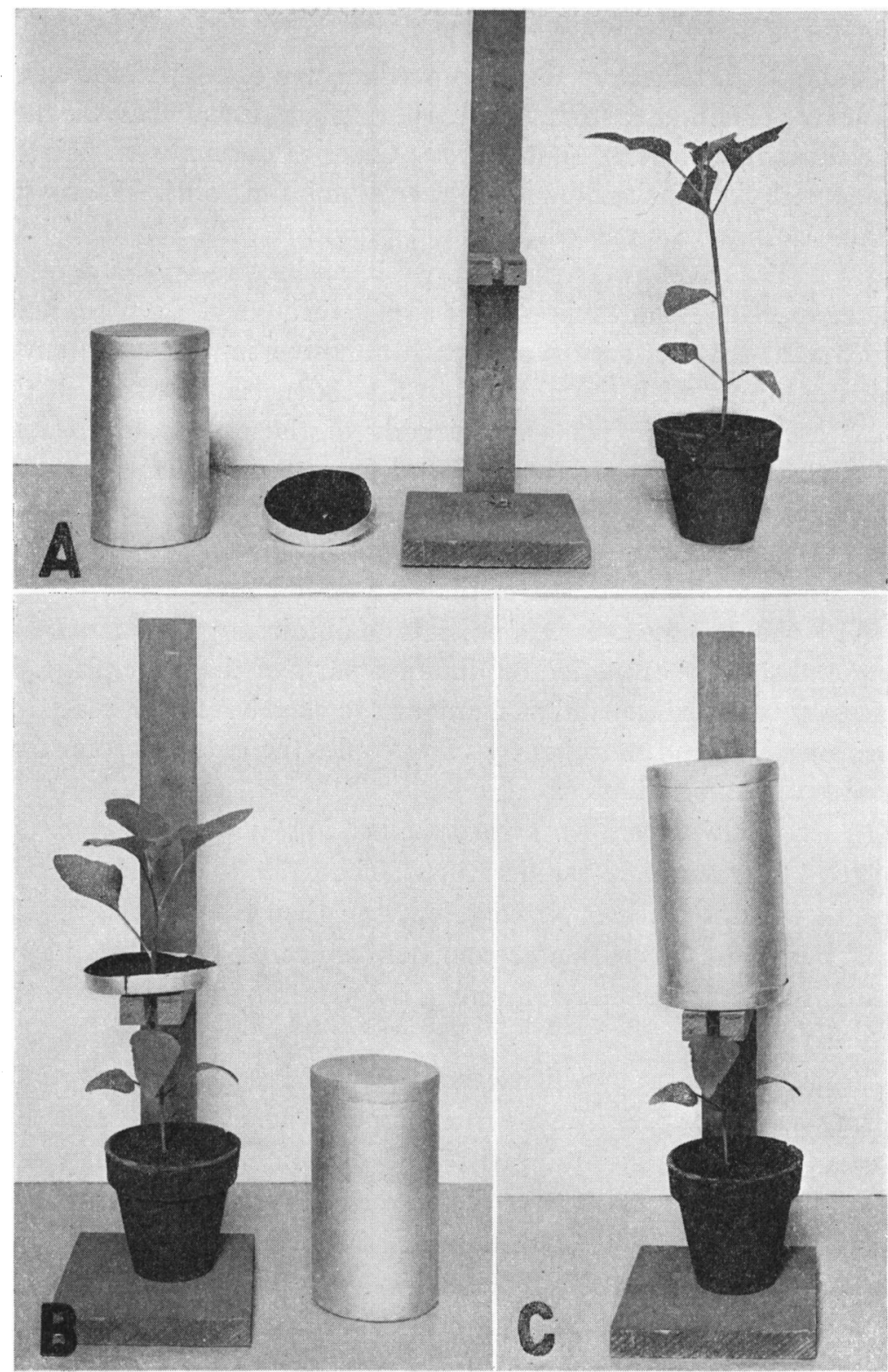

Fig. 3.-Apparatus used to subject whole or parts of plants to same or different photoperiods at same time. $A$ : aluminum coated paper box and cover, wooden standard, and potted plant; $B$ : plant and cover in place; $C$ : box in place for darkening upper portion of plant while lower portion is still exposed to light. 
sidered to represent the flowering condition. As a matter of routine, at least the terminal buds on all the plants of any experiment were dissected about I4 days after its start, in order to determine whether or not floral primordia were present. Figure 4 shows some of the stages of development recognizable upon dissection.

In cases where two large branches per plant were desired, the plants were severed at the first internode when the latter had attained a length of 0.5 to $1.0 \mathrm{~cm}$., or approximately I 5 days after planting the seed. As a result both cotyledonary buds expanded in many cases.

As will be discussed later, it has been found in this work that a portion of a plant exposed to short photoperiod produces an effect upon other portions of the plant not so exposed. In order to facilitate discussion, the portion of the plant on short photoperiod will be referred to as the "donor" portion, and other portions which initiate floral primordia as a result of substances received from this donor will be called "receptor" portions.

\section{Evidence for a specific substance involved in floral initiation}

A given plant response can definitely be linked with a given specific substance only when this substance has been isolated, chemically identified, and shown to be essential to a particular response. Experience with other plant hormones, such as auxins and vitamin $\mathrm{B}_{\mathrm{I}}$, has indicated that correlations within the plant are often to be attributed to chemical substances having the properties of hormones. Floral initiation might be conclusively attributed to the presence of a substance or substances if it could be shown that the effect could be linked to something which is diffusible, can pass out of one plant and back into the same or another plant, and there bring about initiation of floral primordia. Such a substance or substances might be considered as hormones. The results of the detailed experiments which follow give strong indication that hormones are involved in the initiation and development of floral primordia, flowers, and fruits by plants subjected to varying photoperiods and dark periods under certain environmental conditions.

When a Xanthium plant is subjected to short photoperiod, the 


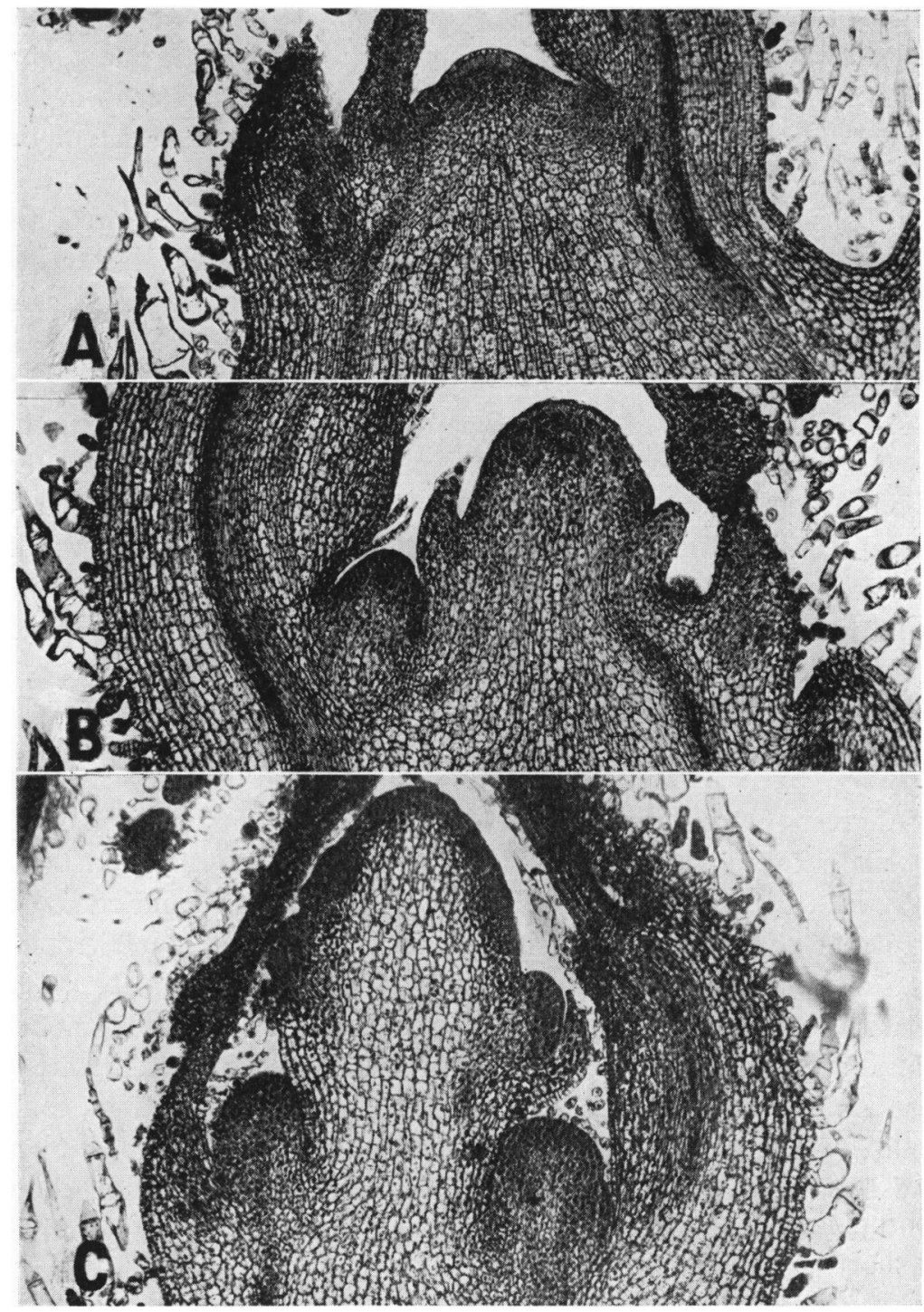

Fig. 4.-Median longitudinal sections of terminal buds of Xanthium. A: strictly vegetative; $B$ : inflorescence primordium; $C$ : later stage in development of inflorescence. Stages between $B$ and $C$ designated as inflorescence primordia in the tables; stages between $C$ and macroscopic flowers designated as flower primordia. 
initial stimulus to floral initiation is received by the leaves, as is shown by three types of experiments.

I. Sturdy vegetative plants were placed on short photoperiods. One lot of these was completely defoliated and the other left undefoliated. The leafy plants were found to have large flower buds after II days. The defoliated plants remained strictly vegetative for 3 weeks, after which the experiment was discontinued (table 5).

2. In other experiments a single fully expanded leaf of each plant was exposed to short photoperiod while the rest of the plant received long photoperiod. These experiments, summarized in table I, show

TABLE $1 *$

FLORAL INITIATION AS RESULT OF EXPOSURE OF SINGLE LEAF TO SHORT PHOTOPERIOD

\begin{tabular}{|c|c|c|c|c|}
\hline $\begin{array}{c}\text { EXPERIMENT } \\
\text { no. }\end{array}$ & TREATMENT & $\begin{array}{c}\text { DURATICN } \\
\text { OF TREAT- } \\
\text { MENT } \\
\text { (DAYS) }\end{array}$ & $\begin{array}{l}\text { No. of } \\
\text { PLANTS }\end{array}$ & $\begin{array}{l}\text { CONDITION } \\
\text { OF PLANT } \\
\text { AT END OF } \\
\text { TREATMENT }\end{array}$ \\
\hline $\begin{array}{l}X-23 \\
\text { and } \\
X-4 I\end{array}$ & $\begin{array}{l}\text { One leaf on short } \\
\text { photoperiod } \\
\text { Untreated controls }\end{array}$ & $\begin{array}{l}\text { I8 } \\
\text { I8 }\end{array}$ & $\begin{array}{r}32 \\
6\end{array}$ & $\begin{array}{l}\operatorname{mac} f f \& f r \\
\text { eeg }\end{array}$ \\
\hline
\end{tabular}

* In this and all subsequent tables the condition of the terminal bud at the time of dissection is indicated as follows:

veg: strictly vegetative.

inf pr: inflorescence primordia.

fl pr: flower primordia.

mac fl \& fr: macroscopic flowers and fruits.

Unless otherwise stated, all plants which received a given treatment were in the same stage of floral development. In all tables the term untreated controls refers to those plants which were maintained on a long photoperiod at the side of the experimental plants, whenever the latter were exposed to long photoperiod, and serve to show whether or not supplementary illumination may have failed at any time during the experiment.

that one leaf exposed to short photoperiod may be sufficient to result in the initiation of flower buds and the development of macroscopic flowers, even though the remainder of the plant is growing on long photoperiod. An example of such a plant after the leaf had received 20 short days is shown in figure 5 .

3. In an experiment of another kind two branched plants were used. One branch received short and the other long photoperiod. In one lot of plants the short day branch or donor was defoliated, and in the other it was left intact. In table 2 it may be seen that if, at the time it is subjected to short photoperiods, the donor branch pos- 


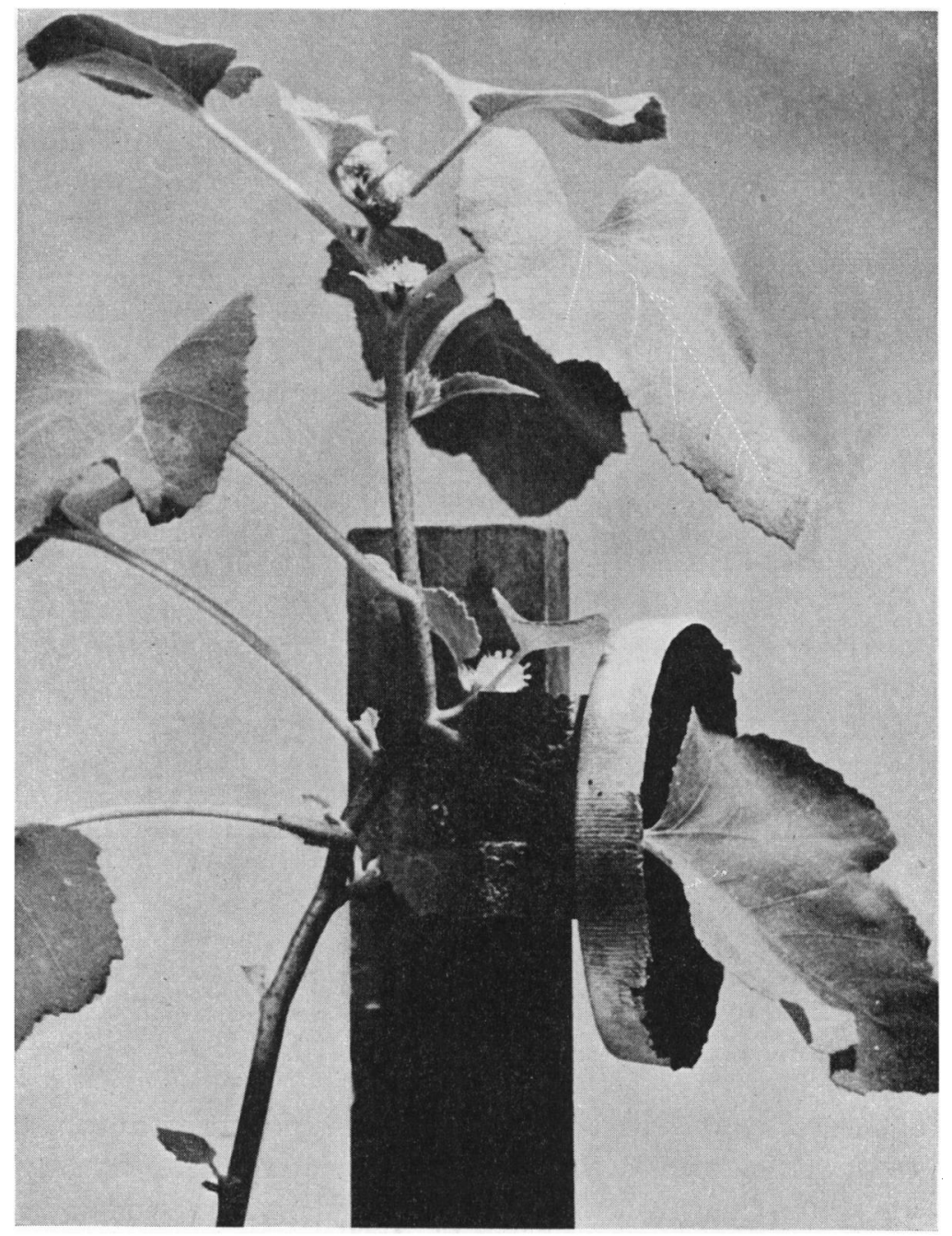

Fig. 5.-Development of flowers on a plant one leaf of which (shown at right of cover) has been exposed to 20 short photoperiods; remainder subjected to long photoperiods only. 
sesses leaves, initiation of flower buds takes place on the donor and receptor branches. If such a short day branch had previously been defoliated, both branches would remain completely vegetative.

A number of experiments were performed in order to determine in what stage of development leaves are most effective in the perception of the photoperiodic stimulus. A group of vegetative plants was selected and divided into four lots. One lot was completely defoliated, one not defoliated in any way, one defoliated except for the young expanding leaves, and the fourth defoliated except for one fully expanded leaf. Of the last lot, the area of the expanded leaf on

TABLE 2

EFFECT OF DEFOLIATION OF BRANCH EXPOSED TO SHORT PHOTOPERIOD ON FLORAL INITIATION IN BRANCH EXPOSED TO LONG PHOTOPERIOD

\begin{tabular}{|c|c|c|c|c|}
\hline $\begin{array}{l}\text { EXPERIMENT } \\
\text { No. }\end{array}$ & TrFatment & $\begin{array}{l}\text { No. of } \\
\text { PLANTS }\end{array}$ & $\begin{array}{l}\text { DURATIGN } \\
\text { OF TREAT- } \\
\text { MENT } \\
\text { (DAYS) }\end{array}$ & $\begin{array}{c}\text { CONDITION } \\
\text { OF RECEPTOR } \\
\text { BRANCH }\end{array}$ \\
\hline$X-37$ & $\begin{array}{l}\text { Donor branch de- } \\
\text { foliated } \\
\text { Donor branch leafy } \\
\text { Untreated controls }\end{array}$ & $\begin{array}{r}6 \\
6 \\
6\end{array}$ & $\begin{array}{l}\text { I4 } \\
\text { I4 } \\
\text { I4 }\end{array}$ & $\begin{array}{l}\text { veg } \\
\text { mac fl \& fr } \\
\text { veg }\end{array}$ \\
\hline
\end{tabular}

any given plant was reduced by cutting away part of it, leaving approximately $2-3 \mathrm{sq} . \mathrm{cm}$., an area about equal to that of the young expanding leaves on other plants. All plants were subjected to short photoperiod, some plants of each lot receiving one short photoperiod (with an accompanying long dark period), other plants two, and so on. During the course of the treatment, as young leaves expanded, the plants were defoliated in order to maintain approximately the same leaf area on any given plant as was present at the start of the experiment (table $\mathrm{I}_{3}$ ).

Undefoliated control plants required but one short photoperiod (with an accompanying long dark period) for the subsequent initiation of floral primordia, while completely defoliated control plants remained vegetative even after ten short photoperiods. The plants which possessed a portion of one mature leaf initiated floral primor- 
dia after receiving three short photoperiods. The plants having an equal area of young leaves, on the other hand, remained strictly vegetative even after seven short photoperiods. This experiment and others indicate that mature leaves are much more effective than are young leaves in the direct perception of the photoperiodic stimulus.

Since the initial photoperiodic stimulus is received by the leaves, the effects of this stimulus must be capable of transport within the plant to reach the bud or buds. A number of special experiments

TABLE 3

MOVEMENT OF STIMULUS TO FLORAL INITIATION WITHIN THE PLANT

\begin{tabular}{c|c|c|c|c}
\hline \hline \multirow{2}{*}{$\begin{array}{c}\text { EXPERIMENT } \\
\text { No. }\end{array}$} & TREATMENT & $\begin{array}{c}\text { No. OF } \\
\text { PLANTS }\end{array}$ & $\begin{array}{c}\text { DURATION } \\
\text { OF TREAT- } \\
\text { MENT } \\
\text { (DAYS) }\end{array}$ & $\begin{array}{c}\text { CONDITION } \\
\text { IN PART OF } \\
\text { PLANT EX- } \\
\text { POSED To } \\
\text { LONG PHOTO- } \\
\text { PERIOD }\end{array}$ \\
\hline $\mathrm{X}-2$ & $\left\{\begin{array}{c}\text { Tip of plant on short } \\
\text { photoperiod; base } \\
\text { on long } \\
\text { Base of plant on } \\
\text { short photoperiod; } \\
\text { tip on long } \\
\text { Untreated controls }\end{array}\right.$ & $\mathrm{I} 2$ & $\mathrm{I} 7$ & $\mathrm{fl} \mathrm{pr}$ \\
& 6 & $\mathrm{I} 2$ & $\mathrm{I} 7$ & $\mathrm{fl} \mathrm{pr}$ \\
$\mathrm{veg}$
\end{tabular}

concerning this movement have been performed. Localized portions of several plants were subjected to short photoperiod. On some several mature apical leaves were so treated; on others, mature basal leaves were used. The remainder of the plant in each case was kept on a I 5.5 hour photoperiod. Other plants, not treated with short photoperiod, were kept on a I5.5 hour photoperiod as controls. Whether the top or the base alone was subjected to short photoperiod, flower primordia formed throughout the length of the plant. Controls remained vegetative (table 3 ). Thus the effect of short photoperiod moves both up and down the stem. This observation was confirmed in many other ways, perhaps the most convincing of which was the type of experiment in which two branched plants were used. One branch was placed under short 
photoperiod, the other under either i6 hour or long photoperiod. Details of such experiments are given in tables 2, I I, I 2, I5, and I6. In every case in which the short day and the long day branch were not defoliated in any way, it was found that the long day branch as well as the short day one initiated floral primordia and developed macroscopic flowers within 2 weeks. The stimulus for floral initiation must therefore be capable of moving down and out of the short day donor portion and up and into the long day receptor portion to the terminal bud of the latter.

That the upward movement of the stimulus probably does not depend upon a passive transport in the transpiration stream is indicated by experiments which were carried out in a nearly saturated atmosphere where transpiration would be expected to be low. Under these conditions also, leaves exposed to short photoperiod at the base of the plant resulted in the initiation of floral primordia at the tip.

The stimulus for the initiation of floral primordia is capable not only of movement within any given plant, but also from one plant to another. A considerable number of splice grafting experiments were carried out in the usual manner, a scion being splice grafted to a stock and the grafted plant placed in a chamber at high humidity and under the desired photoperiod. This method was found to be more difficult to carry out and to be of less wide applicability than the approach graft method, in which portions of the stems of two plants were shaved longitudinally to the cambium and the two shaved surfaces bound together with raffia (fig. 6). The leaves above the graft of one of the plants were then placed on short photoperiod and those of the other kept on long photoperiod. In each experiment two kinds of contacts were made. In the one the union was not interfered with in any way and the stock and scion united within Io days. In the second, or "diffusion contact" type, a layer of lens paper was placed between the two members. Histological examination showed that the paper prevented the formation of a tissue connection for at least $\mathrm{I} 4$ days. In fact, in many cases the two members were found to fall apart as soon as the raffia binding was removed. Only soluble substances should be able to pass across such a diffusion contact. 


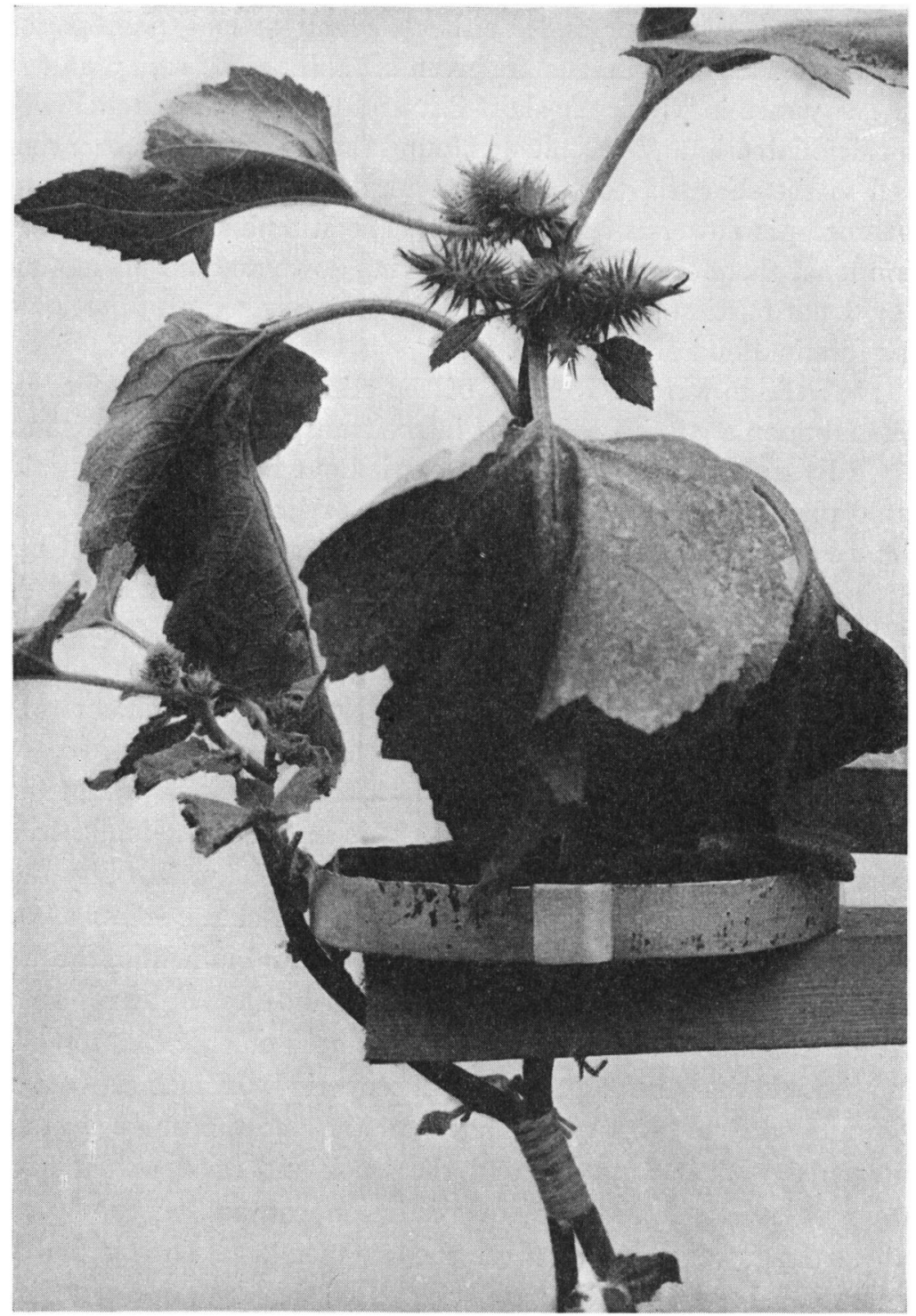

Fig. 6.-Diffusion contact between two vegetative plants on June 28. Subsequent to that date, tip of plant shown above the cover was subjected to short photoperiod, the other defoliated and continued on long photoperiod. Both plants flowered and fruited. Small leaves on plant under long photoperiod developed after experiment was begun. Photograph taken July 26. 
In the experiments recorded in table 4 both plants were initially vegetative. After the graft was made, one member was subjected to short photoperiod and the other to either the long or I 6 hour photoperiods. The stimulus causing floral initiation apparently moved readily across an ordinary graft union, since the long day member of the graft developed floral primordia. This might be expected from the fact that the same stimulus moves so readily within any given

TABLE 4

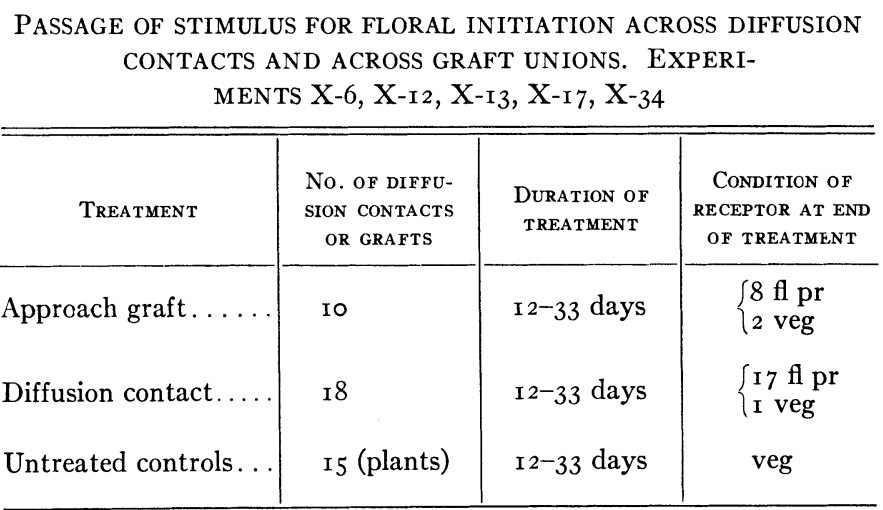

plant. The stimulus is also able to diffuse from one plant merely in close contact with another, indicating definitely that the stimulus is a substance or substances. This is, so far as the writers are aware, the first direct evidence which has been presented concerning this point.

\section{Floral initiation as controlled by length of dark period}

It seems probable that the manufacture of the substance or substances responsible for the initiation of the flowering condition in Xanthium is not primarily a response to duration of the photoperiod, but rather a response to duration of the dark period.

In a preliminary experiment carried out in May, I938, it was found that Xanthium plants grown continuously on photoperiods shorter than I $_{5}$ hours invariably flowered, while plants grown continuously on photoperiods longer than I 5.5 hours failed to initiate floral primordia. In a similar experiment carried out in August, 1938, 
it was found that this critical photoperiod lay between 15.5 and I 5.75 hours' daily illumination. Thus although the critical photoperiod varies somewhat with change of environmental factors, possibly in this case with changes of temperature, still it remained fairly constant during the experimental period. In order to decide whether the "critical day length" is determined primarily by the length of photoperiod or by the length of dark period, experiments were carried out using cycles of other than 24 hours' duration.

The critical photoperiod is as indicated of approximately I 5.5 hours, with the critical dark period of approximately 8.5 hours. If the length of the daily illumination period is the determining factor,

TABLE 5

EFFECT OF COMPLETE DEFOLIATION UPON FLORAL INITIATION IN XANTHIUM PLANTS EXPOSED TO SHORT PHOTOPERIOD

\begin{tabular}{|c|c|c|c|c|}
\hline $\begin{array}{l}\text { EXPERIMENT } \\
\text { No. }\end{array}$ & Treatment & $\begin{array}{l}\text { No. of } \\
\text { PLANTS }\end{array}$ & $\begin{array}{l}\text { DURATION } \\
\text { OF TREAT- } \\
\text { MENT } \\
\text { (DAYS) }\end{array}$ & $\begin{array}{l}\text { CONDITION } \\
\text { OF PLANT AT } \\
\text { END OF } \\
\text { TREATMENT }\end{array}$ \\
\hline X-I & $\begin{array}{l}\text { Completely defoli- } \\
\text { ated } \\
\text { Leafy control }\end{array}$ & $\begin{array}{l}6 \\
6\end{array}$ & $\begin{array}{l}2 \mathrm{I} \\
2 \mathrm{I}\end{array}$ & $\begin{array}{l}\text { veg } \\
\text { mac fl \& fr }\end{array}$ \\
\hline
\end{tabular}

then Xanthium plants should initiate floral primordia on any cycle having photoperiods of less than I 5 hours, and should fail to flower on any cycle having photoperiods longer than i 6 hours. If length of dark period is the determining factor the reverse should be found; plants should initiate floral primordia on any cycle having dark periods longer than 8.5 hours, and should fail to flower on any cycle having dark periods shorter than 8.5 hours, irrespective of shortness of the photoperiod. Since it has been determined that Xanthium initiates floral primordia and flowers profusely on a 24 hour cycle, consisting of an 8 hour photoperiod and a I6 hour dark period, two other cycles were chosen in which the ratio of photoperiod to dark period was also I:2. Thus a $\mathrm{I} 2$ hour cycle, consisting of a 4 hour photoperiod and an 8 hour dark period, and a 48 hour cycle consisting of a 16 hour photoperiod and a 32 hour dark period, were used. Table 6 shows that plants grown on the i 2 hour 


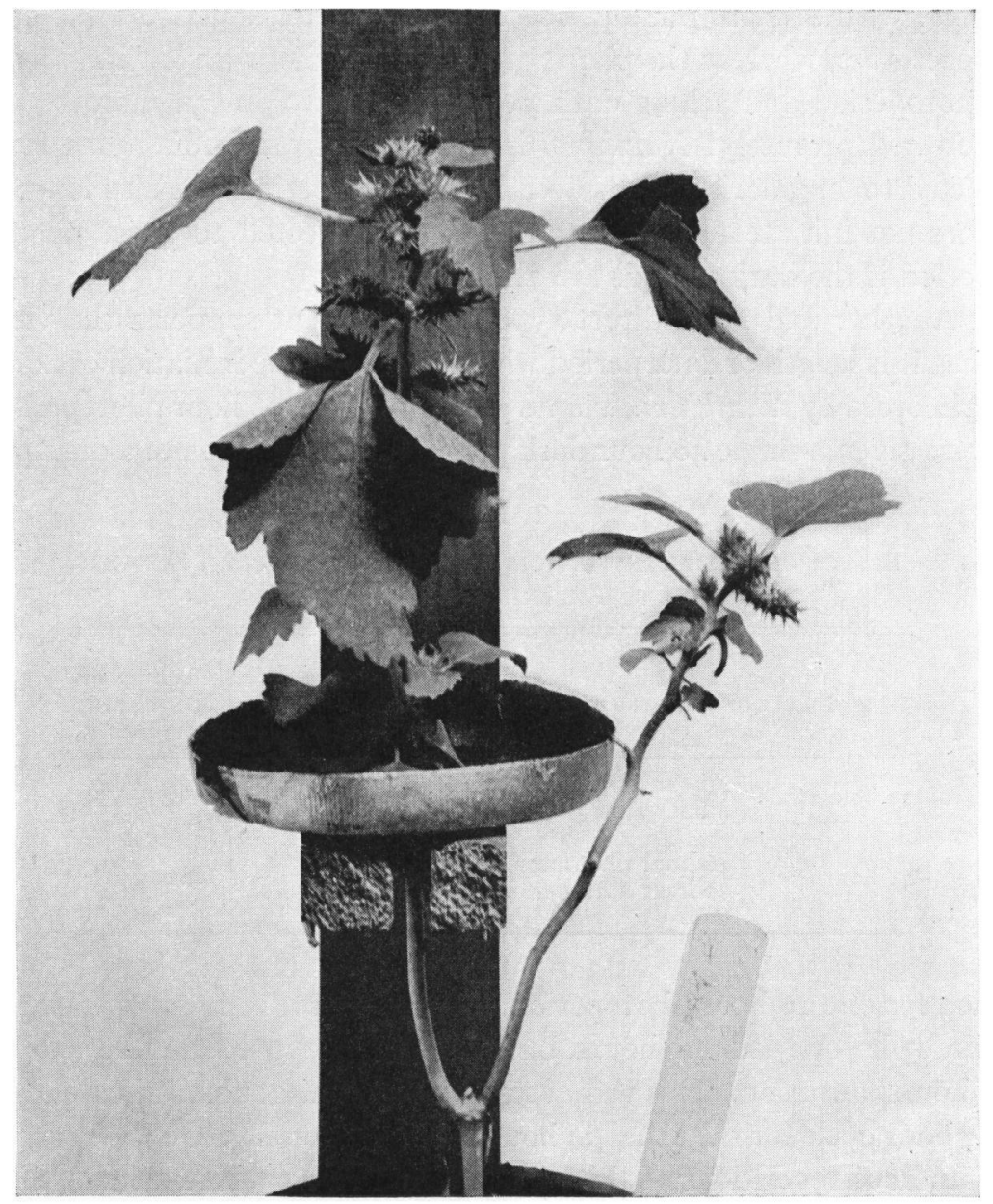

Fig. 7.-At the beginning of the experiment, the two branches of the plant were approximately equal in size, and vegetative. One (donor) was covered and received 33 subsequent short photoperiods; the other (receptor) had the older leaves at the base removed but was continued on long photoperiod. Both shoots fruited. Young leaves on receptor have not prevented initiation of flower primordia nor development of fruits (see fig. 8). 
cycle with a short photoperiod and a short dark period remained vegetative, whereas the plants grown on a 48 hour cycle with a long photoperiod and a long dark period initiated floral primordia and flowered profusely. Xanthium initiates floral primordia when subjected to long dark periods even if the photoperiods are also long; it does not initiate floral primordia when subjected to short photoperiod if the dark periods are also short.

Another and more direct type of experiment supports the view that it is length of dark period which results in the initiation of floral primordia by Xanthium. Plants growing on the $\mathrm{I} 6$ hour photoperiod were given a single 40 hour dark period by substitution of a dark pe-

TABLE 6

EFFECT ON FLORAL INITIATION OF CYCLES OTHER THAN 24 HOURS

EXPERIMENT X-62

\begin{tabular}{|c|c|c|}
\hline LENGTH OF CYCLE AND PHCTOPERIOD & $\begin{array}{l}\text { No. of } \\
\text { PLANTS }\end{array}$ & $\begin{array}{l}\text { CONDITION OF } \\
\text { PLANTS AFTER } \\
\text { I5 DAYS }\end{array}$ \\
\hline I 2 hour cycle $\left\{\begin{array}{l}4 \text { hour photoperiod } \\
8 \text { hour dark period. }\end{array}\right.$ & Io & veg \\
\hline 48 hour cycle $\left\{\begin{array}{l}\text { i } 6 \text { hour photoperiod. } \\
32 \text { hour dark period . }\end{array}\right.$ & Io & $\operatorname{mac} f l \& \mathrm{fr}$ \\
\hline
\end{tabular}

riod for one 16 hour photoperiod. Similar plants were given a single short photoperiod of 9 hours, but with uninterrupted dark periods of 8 hours' duration. This was accomplished by the substitution of one I 7 hour cycle for the usual 24 hour cycle (section II). On the basis of numerous repetitions of this experiment (table 7), it is evident that under certain conditions (see page 409) a single long dark period, unaccompanied by a short photoperiod, is sufficient to result in the subsequent initiation of floral primordia. One short photoperiod unaccompanied by a long dark period has been found to be completely without effect upon the initiation of floral primordia.

If a process involved in the initiation of floral primordia by Xanthium takes place at night, it would seem probable that it is one which is adversely affected by light. That this is the case is demonstrated by the following experiment (table 8). Vegetative plants 
were removed from long photoperiod and placed on a 9 hour photoperiod of daylight in the greenhouse. This was supplemented by 6 hours of artificial light to give a 15 hour photoperiod and a 9 hour dark period, upon which Xanthium flowers abundantly. If, however,

TABLE 7

EFFECT OF EXPOSURE TO ONE LONG DARK PERIOD OR TO ONE SHORT PHOTOPERIOD OR TO BOTH. EXPERIMENTS

$\mathrm{X}-46, \mathrm{X}-3 \mathrm{I}, \mathrm{X}-73$

\begin{tabular}{|c|c|c|}
\hline TYPE OF TREATMENT & $\begin{array}{l}\text { No. of } \\
\text { PLANTS }\end{array}$ & $\begin{array}{c}\text { FLOWERING } \\
\text { RESPONSE }\end{array}$ \\
\hline $\begin{array}{l}\text { Short photoperiod plus short dark period* }{ }^{*} \\
\text { Short photoperiod plus long dark period } \dagger \ldots \\
\text { Long photoperiod plus long dark period.... }\end{array}$ & $\begin{array}{r}4 \\
18 \\
\text { I0 }\end{array}$ & $\begin{array}{l}\text { veg } \\
\operatorname{mac} f l \& \mathrm{fr} \\
\operatorname{mac} f \mathrm{f} \text { fr }\end{array}$ \\
\hline
\end{tabular}

* Other plants treated with similar results (cf. table 6).

+ This treatment has always resulted in the subsequent development of flowers and fruits provided the night temperature is between $2 \mathrm{I}^{\circ}$ and $27^{\circ} \mathrm{C}$. ( $c f$. tables 9 and IO).

TABLE 8

EFFECT OF INTERRUPTION OF DARK PERIOD BY VARYING EXPOSURES TO LIGHT ON FLOWERING OF XANTHIUM. EXPERIMENTS X-43, $\mathrm{X}-60, \mathrm{X}-7 \mathrm{I}$; UNTREATED CONTROLS ALL VEGETATIVE

\begin{tabular}{|c|c|c|c|c|}
\hline $\begin{array}{l}\text { LENGTH OF PHOTO- } \\
\text { PERIOD (HOURS) }\end{array}$ & $\begin{array}{c}\text { LENGTH OF } \\
\text { DARK PERIOD } \\
\text { (HOURS) }\end{array}$ & $\begin{array}{l}\text { LIGHT EXPOSURE DURING } \\
\text { DARK PERIOD }\end{array}$ & $\begin{array}{l}\text { No. of } \\
\text { PLANTS }\end{array}$ & $\begin{array}{l}\text { CCNDITIGN OF } \\
\text { PLANTS AT END } \\
\text { OF TREATMENT }\end{array}$ \\
\hline $\mathrm{I}_{5} \ldots \ldots \ldots \ldots$ & 9 & None & 12 & $\operatorname{mac} f l \& \mathrm{fr}$ \\
\hline I $5 \ldots \ldots \ldots \ldots$ & $4 \cdot 5+4 \cdot 5$ & I minute after 4.5 hours & IO & veg \\
\hline $9 \ldots \ldots \ldots \ldots$ & I5 & None & IO & $\operatorname{mac}$ fl \& fr \\
\hline 9. & $6 \cdot 5+8$ & 30 minutes after 6.5 hours & IO & $\left\{\begin{array}{l}8 \mathrm{n} \mathrm{pr} \\
2 \mathrm{veg}\end{array}\right.$ \\
\hline $9 \ldots \ldots \ldots$ & $5+5+5$ & 30 minutes every 5 hours & IO & $\left\{\begin{array}{l}8 \text { veg } \\
2 \text { infl pr }\end{array}\right.$ \\
\hline $9 \ldots$ & $5+5+5$ & 5 minutes every 5 hours & I 7 & fl pr \\
\hline
\end{tabular}

the 9 hour dark period was divided into two 4.5 hour periods by exposure to artificial light (of ${ }_{5} 0$ foot candles at the leaf surface) of one minute duration, the plants remained strictly vegetative.

In other experiments a 9 hour photoperiod was given and the 15 hour dark period was interrupted at 5 hour intervals, as shown in 
table 8 , by varying lengths of exposure to artificial light of $\mathrm{I} 5 \mathrm{O}$ foot candles at the leaf surface. Control plants on 9 hour photoperiod and with an uninterrupted dark period of I $_{5}$ hours all developed macroscopic flowers within 13 days. Of the plants which received one-half hour of artificial light at 5 hour intervals during the dark period, only two plants out of ten initiated flower buds. When only 5 minutes' exposure to light was given every 5 hours during the 15 hour dark period, all the plants initiated floral primordia. If the 15 hour dark period was interrupted by only one half-hour exposure to light (dividing the dark period into one 8 hour and one 6.5 hour periods), eight out of ten plants initiated floral primordia. Plants which received a 9 hour dark period remained strictly vegetative when a I minute period of exposure to light was given in the middle of the dark period. Thus at least thirty times as much light is required to negate the effect of a 15 hour dark period as is required to negate the effect of a 9 hour dark period.

Still another line of evidence supports the view that certain critical reactions involved in the initiation of floral primordia in Xanthium take place during the dark period. The temperature during the dark period greatly influences its effectiveness in relation to the initiation of flower buds. To test this, plants were removed from long photoperiod and given an 8 hour photoperiod at greenhouse temperature, which during the course of the experiments varied from $20^{\circ}$ to $30^{\circ} \mathrm{C}$. In the evening these plants were placed in the dark at temperatures ranging from $4^{\circ}$ to $38^{\circ} \mathrm{C}$. The following morning the plants were returned to the greenhouse, and a few of them from each lot returned to long photoperiod. This was repeated for ten successive dark periods. The results of one of three experiments are shown in table 9. All experiments gave essentially the same results. Plants given one short photoperiod at average greenhouse temperature, and given one long dark period at temperatures between $2 \mathrm{I}^{\circ}$ and $32^{\circ} \mathrm{C}$., developed floral primordia after being returned to long photoperiod. Thus during one long night sufficient floral initiation substance may accumulate to result in the initiation of floral primordia. If the temperature during the dark period is maintained at $4^{\circ} \mathrm{C}$., seven long dark periods are required to achieve the same result. Temperature 
ranges between $4^{\circ}$ and $2 \mathrm{I}^{\circ} \mathrm{C}$. could not be maintained accurately, but the experiment showed that the higher the temperature up to $2 \mathrm{I}^{\circ} \mathrm{C}$. the fewer the dark periods required. The temperature coefficient of the dark process cannot be determined precisely from this experiment, but in any case it is high, with a $Q_{\text {ro }}$ of approximately 3 and thus of an order which might well be expected of a biochemical process. Table 9 also shows that plants subjected to a temperature of $38^{\circ} \mathrm{C}$. during the dark periods fail to initiate floral primordia even after four long dark periods. The optimum temperature for the most

\section{TABLE 9}

EFFECT OF VARYING TEMPERATURE DURING DARK PERIOD UPON FLORAL INITIATION BY XANTHIUM. EXPERIMENTS X-86 AND X-55. PlantS AT GREenHOUSE TEMPERATURE DURING INTERVENING 9 HOUR PHOTOPERIODS. UNTREATED CONTROL PLANTS VEGETATIVE

\begin{tabular}{|c|c|c|c|c|c|c|c|c|c|c|}
\hline \multirow{2}{*}{$\begin{array}{c}\text { Tempera- } \\
\text { TURE } \\
\left({ }^{\circ} \mathrm{C} .\right)\end{array}$} & \multicolumn{10}{|c|}{ NUMBER OF DARK PERIODS } \\
\hline & I & 2 & 3 & 4 & 5 & 6 & 7 & 8 & 9 & Io \\
\hline $4 \ldots \ldots$ & veg & veg & veg & veg & veg & veg & veg & infl pr & infl pr & infl pr \\
\hline $2 I \ldots \ldots$ & infl pr & infl $\mathrm{pr}$ & infl pr & infl pr & infl $\mathrm{pr}$ & $\ldots$. & $\ldots$ & $\ldots \ldots$ & $\ldots \ldots$ & $\ldots \ldots$ \\
\hline $27 \ldots \ldots$ & infl pr & infl pr & infl pr & infl pr & infl pr & & & $\cdots \cdots$ & $\cdots \cdots$ & $\cdots \cdots$ \\
\hline 32 . & $\left\{\begin{array}{l}9 \text { veg } \\
2 \text { infl pr }\end{array}\right.$ & infl pr & infl pr & infl pr & infl pr & & & & & \\
\hline 38. & veg & veg & veg & veg & & & & & $\cdots \cdots$ & $\cdots$ \\
\hline
\end{tabular}

rapid response to long dark period lies therefore between $2 \mathrm{I}^{\circ}$ and $32^{\circ} \mathrm{C}$.

In contrast to the striking effect of varying temperature during the dark periods, varying temperature during the photoperiods exerts but little effect on the initiation of floral primordia, as is shown by the following experiment. Plants were subjected to a cycle of 8 hour photoperiods and $\mathrm{i} 6$ hour dark periods. The temperature during the dark periods was maintained at approximately $24^{\circ} \mathrm{C}$. Some of the plants were exposed to a temperature of $4^{\circ} \mathrm{C}$. during the photoperiod by placing them for 8 hours each day in a temperature-controlled room containing a carbon arc lamp which supplied an intensity of illumination of approximately 900 foot candles at the leaf surface. The remainder of the plants were subjected 
to photoperiods at greenhouse temperatures of $20^{\circ}$ to $30^{\circ} \mathrm{C}$. Table Io shows that floral primordia were initiated after exposure to one long dark period whether the preceding photoperiod was maintained at $4^{\circ}$ or at $20^{\circ}-30^{\circ} \mathrm{C}$. Although low temperature during the photoperiod was thus without significant effect on the initiation of floral primordia, there was a marked decrease in the rate of subsequent development of the primordia.

There can be but little question that the flowering response of Xanthium to short photoperiod depends primarily upon reactions directly related to the dark period. It may be that the reactions

TABLE 10

EFFECT OF LOW TEMPERATURE DURING PHOTOPERIOD ON FLORAL INITIATION BY XANThIUM. PlantS AT $24^{\circ} \mathrm{C}$. DURING INTERVENING I6 HOURS DARK PERIOD (X-80). Untreated CONTROL Plants Vegetative. Dissection after I6 DAYS

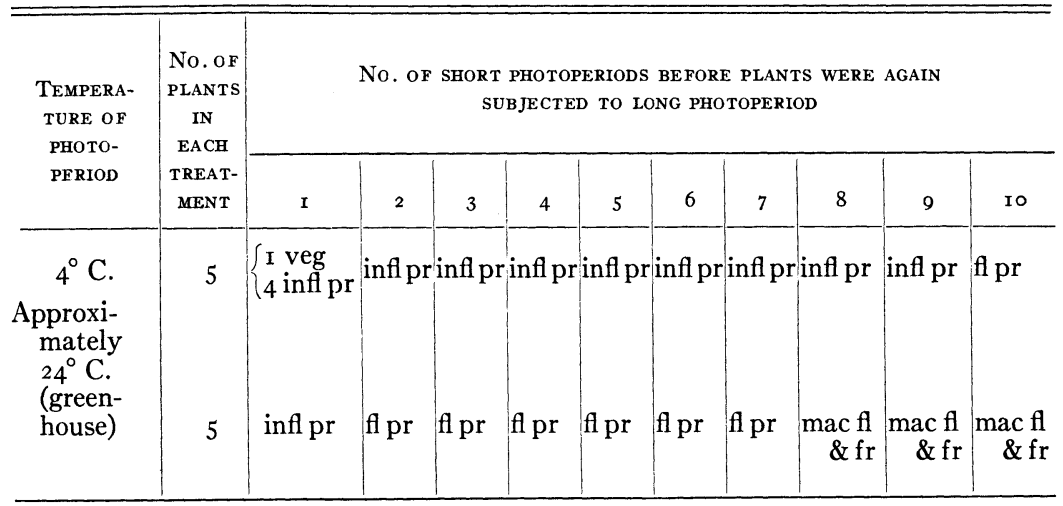

leading to the manufacture of a floral initiating substance are adversely affected by low temperature. At least the responses of Xanthium indicate that, in any critical study of the relationship between temperature and photoperiodism, it is necessary to know the ranges of temperature during the dark period and during the photoperiod.

\section{Nature of inhibition and localization}

It has been shown in section III that if a portion of the Xanthium plant is subjected to short photoperiod, floral primordia are also initiated on other portions of the same plant although such portions 
may be subjected during this same time to long photoperiod. This result might seem to disagree with the reports on localization of the flowering response in other plants (7). Undefoliated Xanthium plants, in fact, do not ordinarily exhibit the strict localization of response to short photoperiod which is found with undefoliated chrysanthemum plants. During the course of the present work a considerable number of experiments were carried out with chrysanthemum. The results were in harmony with those of others (2), namely, that if a portion of a leafy plant was subjected to short photoperiod, macroscopic flowers developed only on such portion,

TABLE 11

EFFECT OF VARIOUS TYPES OF DEFOLIATION ON INITIATION OF FLORAL PRIMORDIA BY RECEPTOR BRANCH. EXPERIMENTS X-24, X-37, X-82.

25 UNTREATED CONTROLS ALL VEGETATIVE

\begin{tabular}{|c|c|c|c|c|}
\hline \multirow[b]{2}{*}{$\begin{array}{l}\text { TYPE OF DEFOLIATION } \\
\text { OF RECEPTOR BRANCH }\end{array}$} & \multirow[b]{2}{*}{ UNDE FOLIATED } & \multicolumn{3}{|c|}{ DE FOLIATED } \\
\hline & & Completely & $\begin{array}{l}\text { EXCEPT FOR } \\
\text { TWO MATURE } \\
\text { LEAVES }\end{array}$ & $\begin{array}{l}\text { EXCEPT FOR } \\
\text { YOUNG EXPAND- } \\
\text { ING LEAVES }\end{array}$ \\
\hline $\begin{array}{l}\text { Condition of receptor after } \\
\text { I } 4 \text { days } \ldots \ldots \ldots \ldots \ldots \ldots \ldots \\
\text { Total plants } \ldots \ldots \ldots \ldots \ldots \ldots\end{array}$ & ${ }_{25}^{\text {infl pr }}$ & ${ }_{24}^{\text {infl pr }}$ & $\begin{array}{l}\text { veg } \\
24\end{array}$ & $\begin{array}{l}\text { fl pr } \\
26\end{array}$ \\
\hline
\end{tabular}

while flowers completely failed to develop on the leafy portion subjected to long photoperiod. An attempt was made therefore to determine whether a localized response to short photoperiod might be obtained with Xanthium, and if so, under what conditions.

In these experiments, summarized in table II, two branched plants were used. The donor branches of all of them were not defoliated nor treated in any way except that they were maintained on short photoperiod. All the receptor branches were maintained on long photoperiod, but on different plants they were subjected to four types of treatment: (I) complete defoliation; (2) removal of the young expanding leaves at the tip, with continued removal of these as additional leaf primordia expanded; (3) removal of only the fully expanded leaves; or (4) not defoliated. Table II shows that only under one condition was a localized response to 
short day obtained, namely, when the young expanding leaves had been removed from the receptor and only the fully expanded ones remained on it (fig. 8). Under these conditions floral primordia were initiated only on the donor whereas the receptor remained strictly vegetative. In all other cases, whether the receptor was completely defoliated or left leafy, floral primordia were initiated on both donor and receptor. If young leaves only were present on the receptor, floral primordia were initiated on it, and these developed into mature flowers and fruits more rapidly than did those on receptors which were either leafy or completely defoliated.

These effects resulting from the presence of immature and mature leaves on receptor branches which receive their stimulus for floral initiation from donor branches subjected to short photoperiod is in direct contrast to the condition prevailing when immature or mature leaves receive the photoperiodic stimulus by being directly subjected to a short photoperiod. In the latter case flower primordia are initiated only if mature leaves are exposed, and are not initiated if immature leaves only are present. The cause of this difference in behavior is not known. At present, largely as a matter of convenience, the failure to initiate and develop floral primordia on receptor branches where only mature leaves are present is referred to as an inhibitory effect of such leaves. The tendency to initiate floral primordia and the rapid development of these into flowers and fruits on receptor branches in the presence of young leaves is referred to as a promotive effect of such leaves.

This inhibitory effect of fully expanded leaves, and the promotive effect of young expanding leaves, on floral initiation on receptor branches were demonstrated repeatedly in separate experiments, as indicated in tables I I and I 2 . The inhibitory effect of fully expanded leaves does not appear to depend upon the extent to which the length of the photoperiod exceeds the critical, but does depend upon the area of such leaves present upon any given branch or plant. This was shown in a series of experiments as follows: Donor branches of 70 two branched plants were subjected to a 9 hour photoperiod. The receptor branches of 35 of these were subjected to a 16 hour photoperiod while the receptors of the remaining 35 were subjected to a 22 


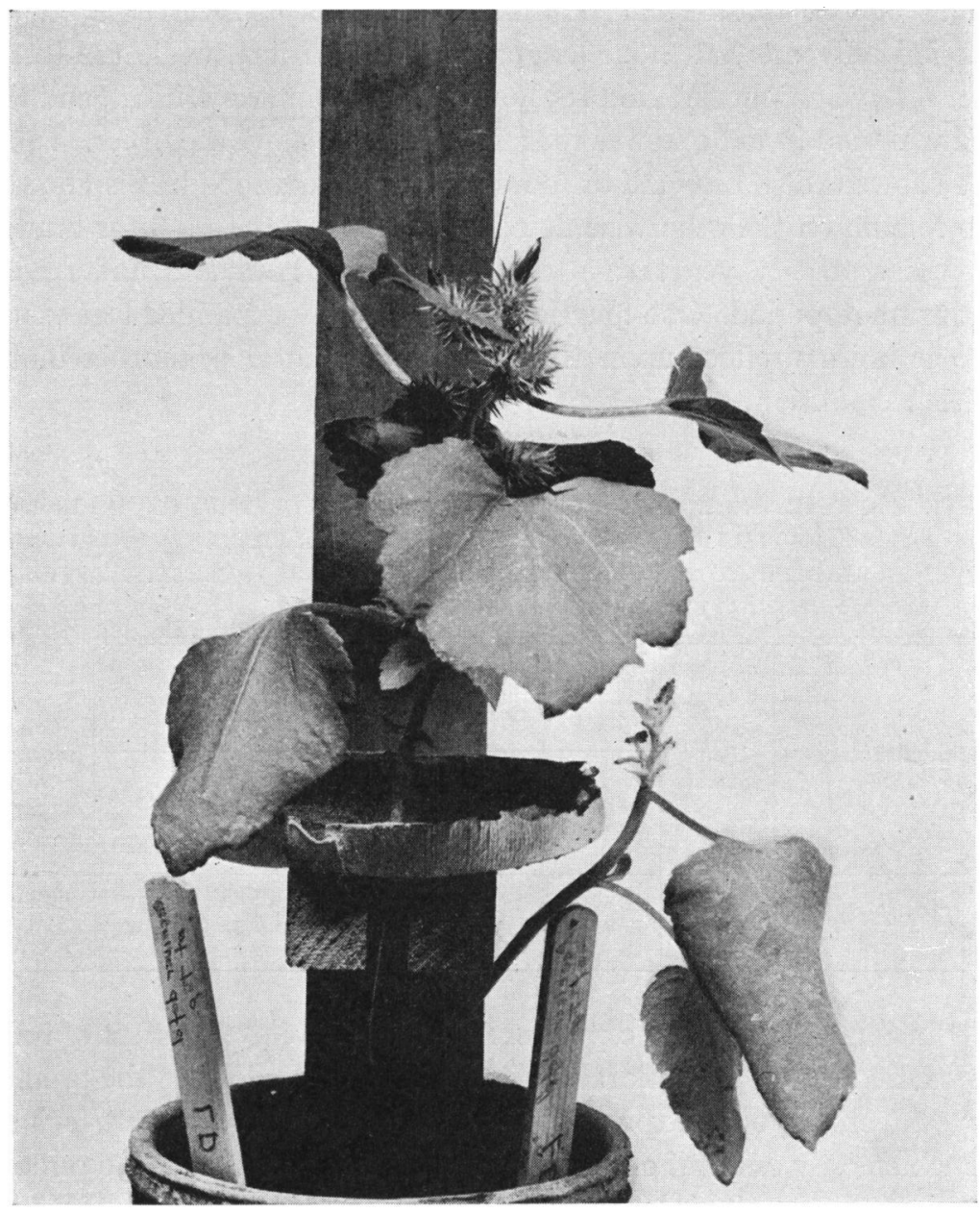

Fig. 8.-At the beginning of the experiment this plant was similar to the plant in fig. 7. The donor was treated in exactly the same manner, but the receptor had the young instead of the mature leaves removed, and was then continued on long photoperiod. The old leaves have prevented initiation of flower primordia and development of fruits on receptor but have exercised no measurable influence in development of flowers and fruits on donor. 
hour photoperiod. Thus the first set of receptors received a photoperiod only one-half hour longer than the critical, while the latter set received a photoperiod 6.5 hours longer than the critical, and the dark period in the one was four times as long as in the other. Table I 2 shows that if one-half or more of a fully expanded leaf is allowed to remain on the otherwise defoliated receptor, the receptor branch remains strictly vegetative both under a 16 hour and under a 22 hour photoperiod. One-fourth or less of a fully expanded leaf exerts no inhibitory effect upon the initiation of floral primordia under either condition.

TABLE 12

EFFECT OF VARYING LEAF AREA AND VARYING PHOTOPERIOD ON INHIBITION OF FLORAL INITIATION BY MATURE LEAVES. DONOR BRANCHES UNDEFOLIATED SUBJECTED TO 9 HOUR PHOTOPERIODS. PlANTS DISSECTED AFTER I4 DAYS; IO UNTREATED CONTROL PLANTS ALL VEGETATIVE

\begin{tabular}{|c|c|c|c|c|c|c|c|}
\hline \multirow{2}{*}{$\begin{array}{c}\text { PHOTOPERIOD TO } \\
\text { WHICH RECEPTOR } \\
\text { WAS EXPCSED } \\
\text { (HOURS) }\end{array}$} & \multirow{2}{*}{$\begin{array}{l}\text { UNDE- } \\
\text { FOLIATED }\end{array}$} & \multicolumn{5}{|c|}{$\begin{array}{l}\text { NATURE OF LEAF ALLOWED TO REMAIN ON } \\
\text { OTHERWISE DEFOLIATED RECEPTOR }\end{array}$} & \multirow{2}{*}{$\begin{array}{l}\text { COM- } \\
\text { PLETELY } \\
\text { DEFOLI- } \\
\text { ATED }\end{array}$} \\
\hline & & $\begin{array}{l}2 \text { MATURE } \\
\text { LEAVES }\end{array}$ & $\begin{array}{l}\text { I MATURE } \\
\text { LEAF }\end{array}$ & $\begin{array}{c}\frac{1}{2} \text { MATURE } \\
\text { LEAF }\end{array}$ & $\begin{array}{l}\frac{1}{4} \text { MATURE } \\
\text { LEAF }\end{array}$ & $\begin{array}{l}\text { I EXPAND- } \\
\text { ING LEAF } \\
\frac{3}{4} " \text { LONG }\end{array}$ & \\
\hline $\begin{array}{l}16 \\
22\end{array}$ & $\begin{array}{l}\text { infl pr } \\
\text { infl pr }\end{array}$ & $\begin{array}{l}\text { veg } \\
\text { veg }\end{array}$ & $\begin{array}{l}\text { veg } \\
\text { veg }\end{array}$ & $\begin{array}{l}\text { veg } \\
\text { veg }\end{array}$ & $\begin{array}{l}\text { infll pr } \\
\text { infl pr }\end{array}$ & $\begin{array}{l}\mathrm{fl} \mathrm{pr} \\
\mathrm{fl} \mathrm{pr}\end{array}$ & $\begin{array}{l}\text { infl pr } \\
\text { infl pr }\end{array}$ \\
\hline
\end{tabular}

Since in the case of receptor branches the inhibitory effect of fully expanded leaves upon floral initiation is in opposition to the promotive effects of young expanding leaves, an experiment was performed in which only one leaf of an intermediate age was allowed to remain on the receptor. This leaf was initially approximately three-quarters of an inch in length and by the end of the 2 weeks' experimental period had developed into a fully expanded leaf. All younger leaves were removed as they began to expand. The single developing leaf, as may be seen in table I 2 , exerted the promotive effect characteristic of young leaves, and this effect does not depend exclusively upon the youngest leaves.

It has been shown that, under certain specific conditions, leaves on long photoperiod are capable of suppressing the initiation of floral 
buds. The question arises as to whether or not this inhibitory effect is localized. In the experiments given in tables 2 , I I, I2, I5, and I6, it was found that on two branched plants the number of floral primordia initiated and the rate of their subsequent development on the donor branch were entirely unaffected by any treatment given

TABLE 13

EFFECT OF APPROXIMATELY EQUAL AREAS OF YOUNG EXPANDING LEAVES OR OF FULLY EXPANDED LEAVES ON INITIATION OF FLORAL PRIMORDIA BY XANTHIUM PLANTS SUBJECTED TO SHORT PHOTOPERIOD (X-77). UNTREATED CONTROLS VEGETATIVE. DISSECTION AFTER I 7 DAYS

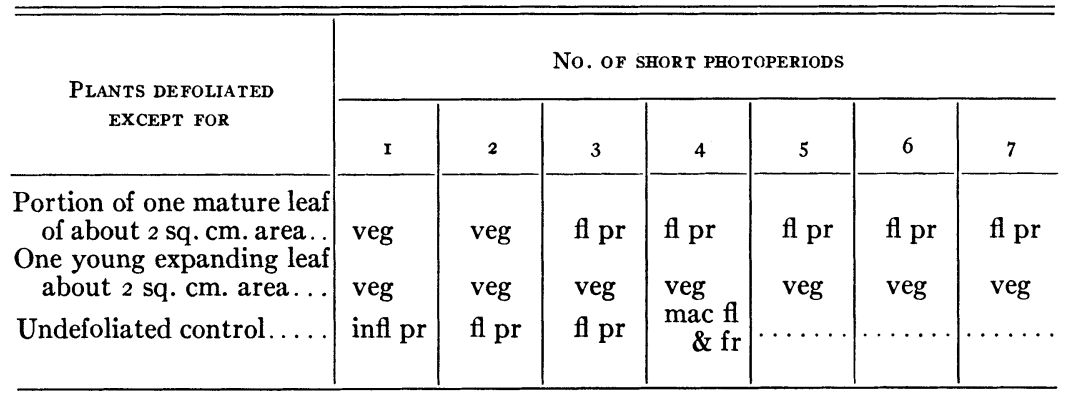

the receptor branch. In these experiments the effect of the leaves on long photoperiod has been apparently confined to the branch exposed to long photoperiod.

\section{Relative response of various buds on a plant}

On any given plant placed upon short photoperiod, a greater total number of flowers and fruits will develop rapidly if the terminal bud is removed. When the terminal bud of a vegetative plant is removed, many lateral buds start to expand at once, and these buds immediately develop flowers and fruits if the plant is on short photoperiod. A similar result is obtained if, instead of removing the terminal bud, the young expanding leaves are removed.

The several buds on any given donor or receptor do not respond alike. In general the buds on the donor branch respond more rapidly and more of them develop into mature fruits than do those of the receptor branch. On any plant, however, the terminal growing point of any branch responds more rapidly than the primordia of axillary buds. Thus if the terminal bud of the donor branch is removed at 
the start of treatment, the terminal growing point of the receptor branch responds more rapidly than do the axillary buds of the donor.

Since the inhibition of the expansion of axillary buds seems to be associated with the presence of young expanding leaves near the tip of the axis, as described, and since the presence of young expanding leaves on the receptor of a two branched plant seems to produce some promotive effect upon the development of flowers and fruits by the receptor branch (section $\mathrm{V}$ ), it is possible that young leaves, through their ability to supply auxin, produce both results. To test this possibility the following experiments were carried out: An attempt was made to replace by the use of indoleacetic acid the promotive effect of young expanding leaves on floral initiation. The receptor branches of two branched plants were defoliated either completely, or by removal of the young expanding leaves at the tip. Indoleacetic acid in lanolin paste ( $\mathrm{I}$ and 0.2 per cent) was then applied to the petiole stumps of the youngest three leaves. Indoleacetic acid applied in these high concentrations was completely without effect on either the initiation of floral primordia or on the development of flowers. Receptor branches, with mature leaves only, remained vegetative even if supplied with indoleacetic acid, as described, and flowers did not develop more rapidly on completely defoliated branches so treated than on untreated defoliated branches.

- In another experiment similar high concentrations of indoleacetic acid as a lanolin paste were applied along the entire length of the stem, and the number of long dark periods necessary for the initiation of floral primordia was compared with the number necessary for untreated control plants. It was found that the untreated control plants, those treated with plain lanolin paste, and those treated with 0.2 per cent indoleacetic acid, all flowered on subsequent long photoperiod if they were subjected to one or more long dark periods. Plants treated with I per cent indoleacetic acid in lanolin, however, flowered only if given two or more long dark periods and not when given one dark period. No effect upon the relative sensitivity of the various buds was found. Thus, although auxin may play some role in the inhibition of flower bud initiation, still this effect is not 
marked, when indoleacetic acid is applied. In numerous experiments carried out as described in section IX, indoleacetic acid was also without activity in initiating floral primordia in Xanthium. What relation this may bear to the well known effect of indoleacetic acid in suppression of bud development was not investigated.

\section{Nature of induction}

In the preceding sections consideration has been given mainly to the initiation of floral primordia by Xanthium. It has been observed during these experiments, as well as in those of others (4), that initiation of floral primordia by the influence of suitable photoperiod is accompanied by other striking aftereffects when the plant is subsequently transferred to other photoperiods.

If a vegetative Xanthium plant is removed from long photoperiod, subjected to one long dark period under suitable environmental conditions (section IV), and returned to long photoperiod, this plant will initiate floral primordia and will develop macroscopic flowers after approximately I4 days. During the single long dark period no histologically detectable change occurs in the plant. Nevertheless some change has been brought about, a change which results in its flowering when grown subsequently on long photoperiod. This phenomenon, which is essentially one of photoperiodic aftereffect, may be referred to as photoperiodic induction. Induction in this sense is not the initiation of floral primordia per se, but is rather the change within the plant which takes place in relation to an alternation of photoperiods and dark periods which results in the initiation of floral primordia. Under suitable conditions of temperature this change may be brought about in Xanthium by subjection to one or more long dark periods. Subsequent flowering results whether the photoperiods following the long dark period are long or short. Induction appears to be associated with some alteration in metabolism, and experiments have been performed to investigate the nature of this alteration.

Plants which have undergone induction continue to supply the floral initiation substance when subsequently subjected to long photoperiods. This was demonstrated by the use of plants which 
had been induced by exposure to 24 short photoperiods, and which were approach grafted to defoliated vegetative plants. Both plants were then allowed to remain on long photoperiod. The results are shown in table I4.

This ability of induced plants to continue to supply the floral initiation substance when such plants are returned to long photoperiod, might be attributable to (a) the storage of reserves of it during the exposure to short photoperiod and usage of this supply during the following long photoperiods, or (b) an alteration of the metabolism of the plant such that it manufactures the substance even

TABLE 14

PLANTS INDUCED BY EXPOSURE TO SHORT PHOTOPERIOD CONTINUE TO SUPPLY FLORAL INITIATION SUBSTANCE EVEN WHEN SUBSEQUENTLY SUBJECTED TO LONG PHOTOPERIOD. UNTREATED CONTROLS VEGETATIVE

\begin{tabular}{|c|c|c|c|c|}
\hline $\begin{array}{l}\text { EXPERIMENT } \\
\text { No. }\end{array}$ & Treatment & $\begin{array}{c}\text { No. } \\
\text { OF GRAFTS }\end{array}$ & $\begin{array}{c}\text { TIME OF } \\
\text { OBSERVATIONS }\end{array}$ & $\begin{array}{l}\text { CONDITION } \\
\text { OF RECEPTOR }\end{array}$ \\
\hline $\begin{array}{l}\mathrm{X}-\mathrm{I} 2 \\
\text { and } \\
\mathrm{X}-\mathrm{I} 7\end{array}$ & $\begin{array}{l}\text { Photoperiodically in- } \\
\text { duced donor graft- } \\
\text { ed to vegetative } \\
\text { receptor }\end{array}$ & 8 & $14^{-22}$ days & $\left\{\begin{array}{l}6 \mathrm{infl} \mathrm{pr} \\
2 \mathrm{veg}\end{array}\right.$ \\
\hline
\end{tabular}

when subjected to long photoperiods. A final decision between these two alternatives is not possible at the present time, but a number of considerations indicate that the latter may be the more probable, as is illustrated by the following experiment: Small vegetative Xinthium plants were subjected to seven short photoperiods during and after which periods they initiated floral primordia and bloomed. They were then grown under continuous illumination for 7 months. After this they continued to receive long photoperiods for a total duration of more than one year. During this period the plants increased in size 10o or more times, and produced many new shoots. They also continued to produce flowers, although new axillary shoots occasionally developed vegetatively for a time. It would seem unlikely that floral initiation and flower development substances stored in the young plants during the seven consecutive short photoperiods could be responsible for this striking aftereffect. It seems more prob- 
able that these plants continued to manufacture the substances in question during the exposure to long photoperiods. These plants have in effect become indeterminate or everblooming with respect to photoperiod.

It has been a common experience during the course of the present work to find that the development of floral primordia into mature flowers is much slower for a plant which has been induced by one long dark period, than for one given a succession of long dark periods. Thus the rapidity with which a plant supplies the sub-

TABLE 15

EFFECT OF VARYING EXPOSURES OF DONOR BRANCH TO SHORT PHOTOPERIOD ON DEVELOPMENT OF FLOWERS AND FRUITS ON RECEP-

TOR AFTER REMOVAL OF DONOR. DISSECTION AFTER 2I DAYS

\begin{tabular}{|c|c|c|c|}
\hline EXPERIMENT NO. & $\begin{array}{l}\text { NO. OF SHORT } \\
\text { PHOTOPERIODS TO } \\
\text { WHICH DONOR } \\
\text { WAS EXPOSED }\end{array}$ & $\begin{array}{l}\text { No. of } \\
\text { PLANTS }\end{array}$ & $\begin{array}{l}\text { SUBSEQUENT DE- } \\
\text { VELOPMENT OF } \\
\text { FLOWERS AND } \\
\text { FRUITS ON } \\
\text { RECEPTOR }\end{array}$ \\
\hline $\begin{array}{l}\mathrm{X}-53 \ldots \ldots \\
\mathrm{X}-53 \ldots \ldots \\
\mathrm{X}-53 \ldots \ldots \\
\mathrm{X}-25 \ldots \ldots \ldots \\
\mathrm{X}-24 \ldots \ldots \ldots\end{array}$ & $\begin{array}{r}2 \\
4 \\
8 \\
\text { I I } \\
27\end{array}$ & $\begin{array}{r}5 \\
5 \\
5 \\
4 \\
20\end{array}$ & $\begin{array}{l}\text { veg } \\
\text { fl pr } \\
\text { fl pr } \\
\text { fl pr } \\
\text { mac fl \& fr }\end{array}$ \\
\hline
\end{tabular}

stances necessary for floral development seems to depend to a certain extent upon the length of the induction period.

The ability to supply these substances necessary for floral development seems to be transferable from one branch to another. This has been demonstrated in several experiments in which a number of lots of two branched plants were used. In these the donor branches of each lot were subjected to a definite number of short photoperiods. Then the donor branch was severed from the plant, while the receptor branch was in every case maintained under conditions of long photoperiod. The development of flowers and fruits on these receptor branches was then observed at intervals. The results of three such experiments are given in table ${ }^{5} 5$. If the donor received but two short photoperiods before it was removed, the receptor remained strictly vegetative, even after 30 days. If, however, the 


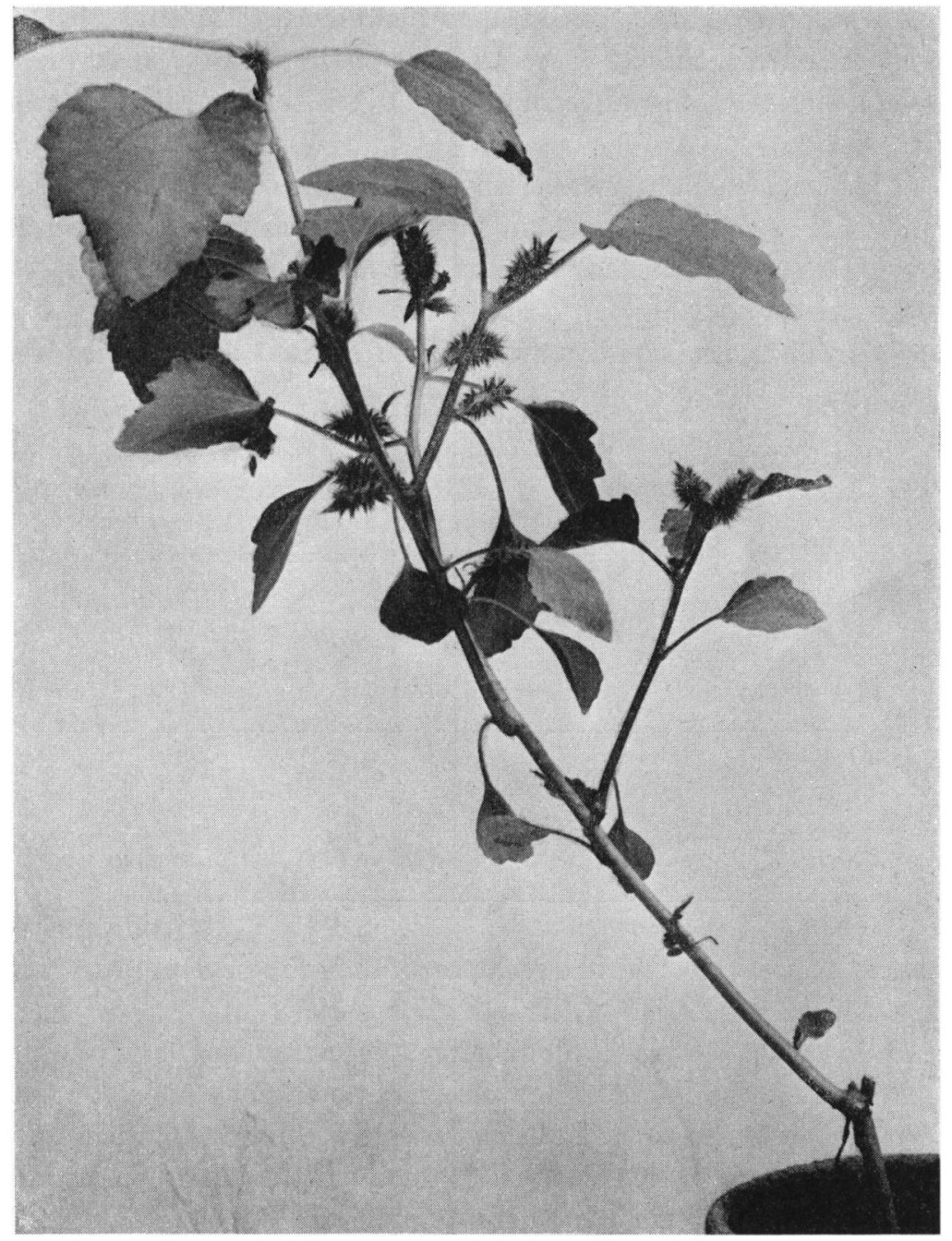

FIG. 9.-Receptor branch of two branched plant of which the donor received 27 short photoperiods and was then removed. At the time of removal, all macroscopic flowers and fruits were removed from the receptor (fruits shown have developed subsequent to that time). Photograph taken 40 days after removal of donor. 
donor received four short photoperiods and was then removed, floral primordia were subsequently initiated on the receptor, and these primordia continued to develop somewhat further, although slowly. In one experiment the donor received twenty-seven short photoperiods before it was removed. During this period the receptor had developed macroscopic flower and fruits. All such flowers and fruits were removed from the receptor when the donor was cut off. Forty days later numerous flowers and fruits had again developed on these receptor branches, which had themselves never been subjected to short photoperiod. An example of such a receptor is given in figure 9. It is evident that if the donor branch is exposed to a sufficient number of short photoperiods the receptor may behave in some respects as if directly photoperiodically induced; that is, changed in a manner which results in the continued production of flowers and fruits even when it is subjected to uninterrupted long photoperiods.

Such indirect induction at least partially depends upon the leaves of the donor and is accelerated if the buds on the donor are removed (fig. IoB). The plants shown are of a series whose donors received eleven short photoperiods. At the end of this time all the receptor branches possessed floral primordia. The plants were then divided into four lots and the donor branches of any given lot were subjected to one of the following treatments: (I) severed from the receptor, (2) disbudded and exposed to long photoperiod, (3) defoliated and exposed to long photoperiod, and (4) left intact and exposed to long photoperiod. In figures io and I a typical receptor of each group is shown after a development of 40 days following the respective treatments. In the cases where the buds of the donor were removed but the leaves allowed to remain, the receptor possessed numerous large fruits. Where the donor had been removed, the buds of the receptor had developed but little. The other two cases exhibit intermediate development of flowers on the receptor. Removal of the buds on the donor at the end of the short photoperiod treatment thus greatly accelerates the subsequent development of flowers and fruits on the receptor.

In another experiment 40 two branched plants were used. These 


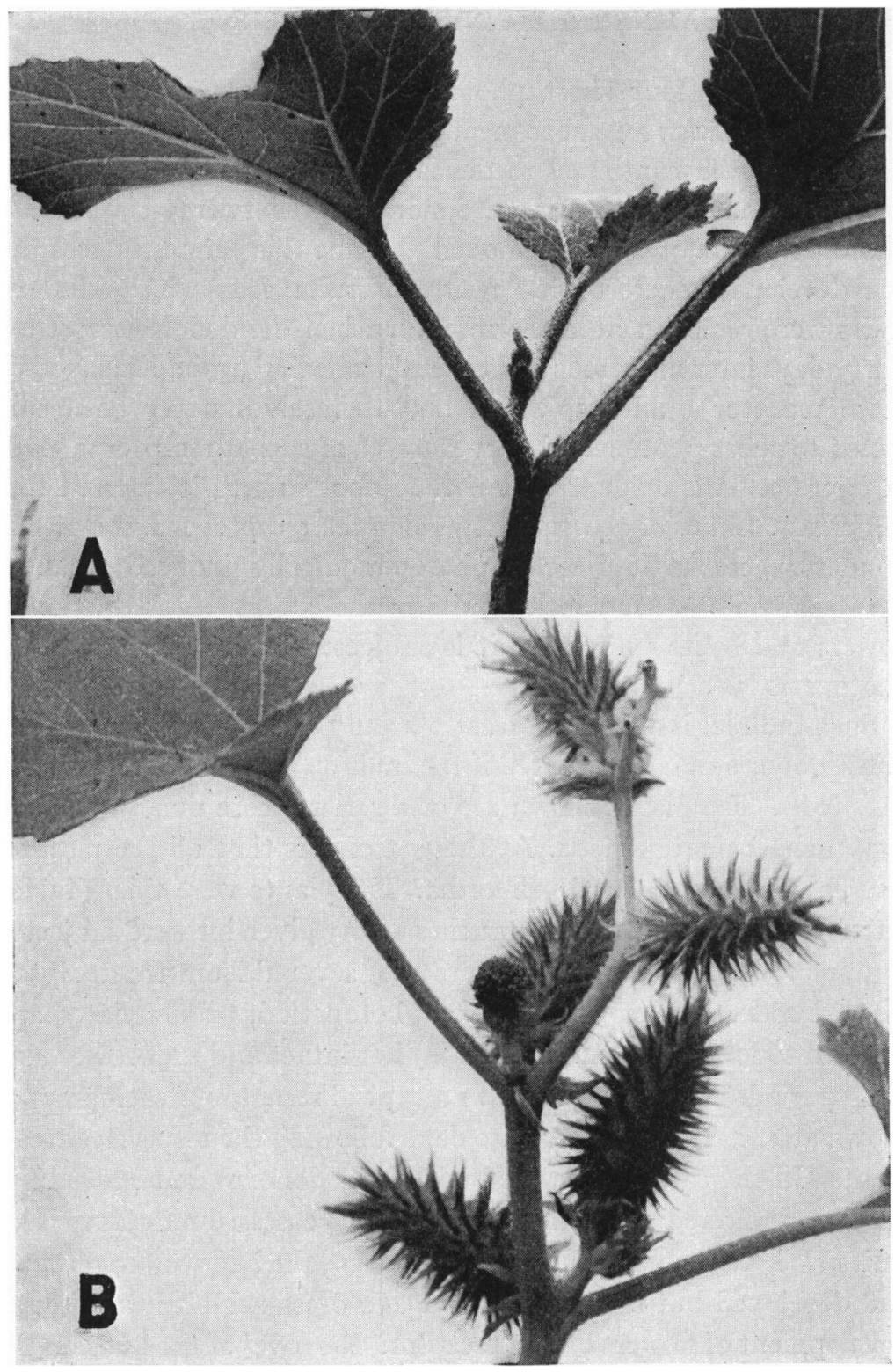

Fig. Io.- $A$ : receptor branch of two branched plant whose donor received i i short photoperiods and was then immediately removed. $B$ : receptor branch of a two branched plant whose donor branch after having received in short photoperiods, was not removed but had its terminal and all its axillary buds removed. Note that although both receptors were grown continuously under long photoperiod, $A$ has macroscopic flowers only and $B$ well developed burs. Photograph taken $4 \mathrm{r}$ days subsequent to beginning of treatment. 


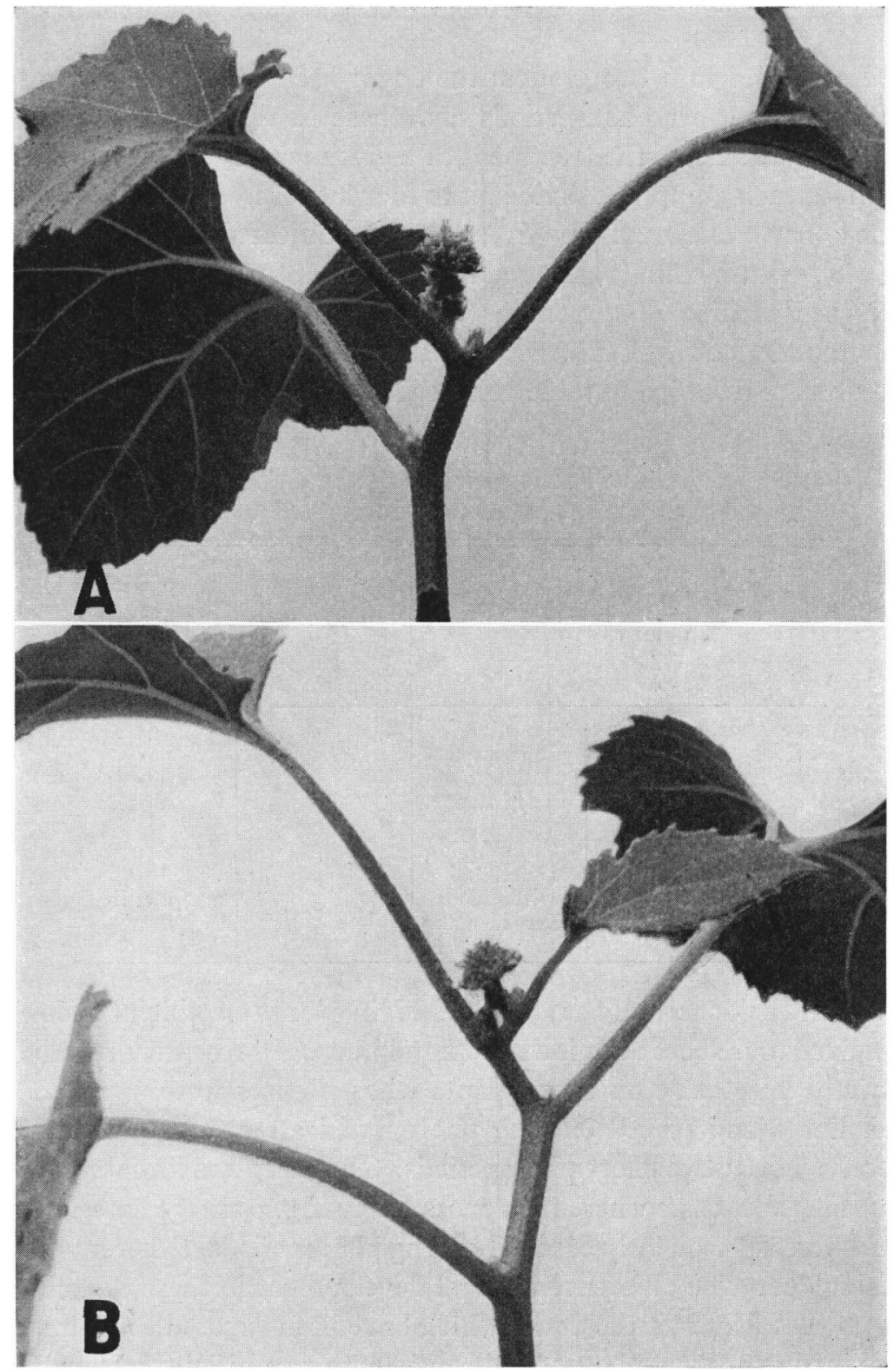

Fig. II.-A: receptor branch of two branched plant whose donor received in short photoperiods and was then defoliated. $B$ : receptor branch of two branched plant whose donor branch received II short photoperiods and was not subjected to further treatment other than being continued on long photoperiod. Note that $A$ and $B$ are intermediate with respect to floral development between $A$ and $B$ of fig. 10 . 
were divided into two groups; the donor branches of one group received two short photoperiods and those of the second group received four. After the treatment of a given group with short photoperiod, each group was divided into four lots of five plants each, and the donor branches of any given lot were subjected to one of the following treatments: (I) severed from the receptor, (2) disbudded and exposed to long photoperiod, (3) defoliated and exposed to long photoperiod, or (4) left intact and exposed to long photoperiod. The results are recorded in table $\mathrm{I} 6$. Regardless of the subsequent treat-

TABLE 16

EFFECT OF VARIOUS TREATMENTS OF DONOR ON DEVELOPMENT OF FLOWERS AND FRUITS BY RECEPTOR. EXPERIMENT X-53

\begin{tabular}{|c|c|c|c|}
\hline \multicolumn{2}{|c|}{ TREATMENT OF DONOR } & $\begin{array}{l}\text { No. of } \\
\text { PLANTS }\end{array}$ & $\begin{array}{l}\text { DEVELOPMENT OF } \\
\text { FLOWERS AND } \\
\text { FRUITS ON RE- } \\
\text { CEPTOR AFTER } \\
\text { 2I DAYS }\end{array}$ \\
\hline $\begin{array}{l}\text { Two short photope- } \\
\text { riods then placed } \\
\text { on long photoperi- } \\
\text { od and }\end{array}$ & $\begin{array}{l}\text { Cut off } \\
\text { Defoliated } \\
\text { Disbudded } \\
\text { Left intact }\end{array}$ & $\begin{array}{l}5 \\
5 \\
5 \\
5\end{array}$ & $\begin{array}{l}\text { veg } \\
\text { veg } \\
\text { fl pr } \\
\text { fl pr }\end{array}$ \\
\hline $\begin{array}{l}\text { Four short photope- } \\
\text { riods then placed } \\
\text { on long photoperi- } \\
\text { od and }\end{array}$ & $\begin{array}{l}\text { Cut off } \\
\text { Defoliated } \\
\text { Disbudded } \\
\text { Left intact }\end{array}$ & $\begin{array}{l}5 \\
5 \\
5 \\
5\end{array}$ & $\begin{aligned} & f l \mathrm{pr} \\
& \mathrm{fl} \mathrm{pr} \\
& \operatorname{mac} \mathrm{fl} \& \mathrm{fr} \\
& \mathrm{fl} \mathrm{pr}\end{aligned}$ \\
\hline
\end{tabular}

ment of the donor, all the receptors of the plants on which the donor received four short days initiated floral buds. All receptors remained strictly vegetative on those plants whose donors were removed or defoliated and placed on long photoperiod after these donors had received only two short photoperiods. The receptors initiated floral buds in those cases where the donors received two short photoperiods and were subsequently exposed to long photoperiods, either intact or disbudded. The difference in floral development in these cases indicates that leaves of the donor which have been exposed to an induction period of short photoperiod continue to supply substances which bring about initiation and development of floral primordia in the receptor, even after these leaves are subsequently placed on long photoperiod. 


\section{Attempts to determine nature of floral initiation substance}

On the basis of the observation that the floral initiation substance diffuses from a plant subjected to short photoperiod into a vegetative plant exposed to long photoperiod and brings about the initiation of floral primordia by the latter, attempts were made to extract the floral initiation substance from leaves which had been subjected to short photoperiod, and by the use of such extract to bring about floral initiation in vegetative plants or cuttings.

Several test methods were employed for supplying such extracts to vegetative plants maintained on long photoperiods. A desirable

TABLE 17

\section{RESPONSE OF XANTHIUM CUTTINGS TO LONG AND SHORT PHOTOPERIODS}

\begin{tabular}{|c|c|c|c|}
\hline EXPERIMENT NO. & TREatment & $\begin{array}{c}\text { No. of } \\
\text { Cutrings }\end{array}$ & $\begin{array}{l}\text { CONDITION OF } \\
\text { CUTTINGS AFTER } \\
\text { I } 4 \text { DAYS }\end{array}$ \\
\hline $\begin{array}{l}X-14 \\
\text { and } \\
X-29\end{array}$ & $\begin{array}{l}\text { Short photoperiod } \\
\text { Long photoperiod } \\
\text { I } 6 \text { hour photoperiod }\end{array}$ & $\begin{array}{l}\text { I } 5 \\
\text { IO } \\
\text { IO* }\end{array}$ & $\begin{array}{l}\text { fl pr } \\
\text { veg } \\
\text { veg }\end{array}$ \\
\hline
\end{tabular}

* Approximately 4500 cuttings have been subjected to 16 hour photoperiod and have remained strictly vegetative in other experiments.

method would be one in which vegetative shoots kept on days longer than the critical would be able to take up the solution to be tested. It is also necessary that the control plants remain vegetative. Cuttings were used most extensively as test material. Sturdy vegetative plants $3-4$ weeks old were severed above the cotyledonary node, and defoliated below the uppermost partly expanded leaf. These cuttings were tied in groups of four or five and placed in $20 \mathrm{cc}$. shell vials containing the solutions to be tested. It is shown in table I 7 that if such cuttings are placed in water and exposed to short photoperiod, they respond readily in the production of floral primordia and of macroscopic flowers. When similar cuttings were subjected to I6 hour photoperiod or to long photoperiod they remained strictly vegetative. Cuttings respond to short day with floral initiation just as do intact plants, and it would seem justifiable to make use of such 
cuttings as test material for the detection of the floral initiation substance.

In all of the cutting tests to be described, the cuttings were maintained under either a 15.5 or a 16 hour photoperiod. The humidity was adjusted so that approximately io cc. of solution per four cuttings per day was lost by transpiration. That solutions or extracts supplied to the cuttings were actually taken up was shown by the marked toxic effects of certain solutions upon the upper leaves of the cuttings, and by the marked effects which certain solutions exerted on vegetative growth (stem elongation, rooting, etc.). In most cases the solutions were renewed daily.

The vials containing the cuttings were placed in numbered racks each holding ten or twenty vials. It was found possible to test as many as twenty-five racks ( 250 solutions) at one time. After a standard arbitrary time of two weeks under any particular test, the cuttings were dissected under the binocular microscope and inspected for floral primordia. As shown in table 16 , this period is approximately twice as long as is required for the initiation of detectable floral primordia by similar cuttings subjected to short photoperiod.

A number of the substances known to possess activity as plant growth factors were investigated by the cutting test for possible activity in floral initiation. Thus vitamins $B_{1}, B_{2}, B_{6}$, ascorbic acid, pantothenic acid, nicotinic acid, inositol, indoleacetic acid, theelin, and theelol were used over wide ranges of concentrations. Yeast extract, which contains several of these growth factors, was also used. All these substances were found to be completely without activity in initiating floral primordia on Xanthium cuttings. Vitamin $\mathrm{B}_{\mathrm{I}}$, theelin, and yeast extract were also supplied in the nutrient solution given to Xanthium plants in sand culture and maintained under long photoperiod. Despite the great promotive effects of these materials on growth, the plants remained strictly vegetative. In another experiment vitamins $B_{1}$ and $B_{6}$, pantothenic acid, and nicotinic acid were supplied to vegetative Xanthium plants through funnels of appropriate size attached to the stump of the decapitated epicotyl. These plants also remained vegetative. It seems probable that the substance responsible for floral initiation is not identical with any of these known plant growth factors. 
Vitamin $\mathrm{B}_{\mathrm{I}}$, ascorbic acid, theelin, theelol, and yeast extract were also investigated for possible promotive effects upon the development of chrysanthemum flowers. Plants of a late flowering clone were subjected to eight short photoperiods, after which they were found to have microscopically detectable floral primordia. They were then returned to long photoperiod, transplanted to sand, and supplied with nutrient solution containing various concentrations of the above growth factors. No effect upon the continued development of the microscopic floral primordia into macroscopic flowers was found in any case.

Since the work of GARNER and others (8) has shown that the initiation of the flowering state by appropriate photoperiod is associated with changes of acidity, a number of the common organic acids found in plants were tested, each over a wide range of concentrations, for possible effects on floral initiation on Xanthium cuttings. Succinic acid, malic acid, tartaric acid, citric acid, fumaric acid, oxalic acid, and maleic acid were found to be without effect, as were also the amino acids arginine, lysine, and glutamic acid.

Two hundred and forty-six different kinds of extracts and extract fractions were made during the course of attempts to extract the floral initiation substance from leaves. Extraction with several solvents, such as water, ethyl alcohol, ether, chloroform, acetone, benzene, and pyridine, was employed, and both fresh and ovendried leaves were used. Considerable precaution was exercised in the treatment of these extracts. All concentrations and evaporations were done in an atmosphere of $\mathrm{N}_{2}$ under diminished pressure and below $60^{\circ} \mathrm{C}$. in general, to decrease possible oxidation of the active material. Each extract was tested in several concentrations, so that more than II 50 solutions were tested, and approximately 4500 cuttings dissected. About half of the extracts were of leaves from Xanthium plants which had been subjected to short photoperiod; but extracts of other short day plants, as well as of indeterminate and long day plants, all in the flowering state, were prepared. None of these extracts showed any activity in bringing about the initiation of floral primordia on Xanthium cuttings when tested in the manner described.

There are indications, however, that if the vegetative cuttings are 
treated by slight modifications of the procedure here outlined, they may respond with the initiation of floral primordia to the application of a simple water extract of leaves from induced Xanthium plants.

\section{Discussion}

The response of Xanthium to photoperiod appears to differ in some respects from that of certain other photoperiodically sensitive plants which have been investigated. The strict localization of the response which has been reported for leafy plants of cosmos (7), chrysanthemum (2), and of other plants, is not found in leafy plants of Xanthium. In the species other than Xanthium, leaves of shoots subjected to conditions of long photoperiod prevent the initiation of floral primordia upon such shoots, even though other portions of the same plant are subjected to conditions of short photoperiod. Localization of this kind can be obtained with Xanthium provided only mature, fully expanded leaves are allowed to remain on a receptor shoot subjected to long photoperiod. Mature leaves of Xanthium thus behave in this respect in a manner similar to the leaves of some of the other plants so far investigated. Young expanding leaves of Xanthium, on the contrary, appear to exert a promotive effect on floral initiation and flower development in receptor branches.

Xanthium differs from soy bean ( $\mathbf{I}$ ), chrysanthemum, and cosmos (7) in that exposure of a Xanthium plant to a number of short photoperiods sufficient to result in the initiation of floral primordia also results in the development of these primordia into mature flowers and fruits, despite subsequent maintenance under conditions of long photoperiod. Plants of the other species under similar conditions initiate floral primordia but these frequently do not develop into mature flowers or fruits unless exposed to a still longer induction period.

Xanthium plants initiate floral primordia after exposure to one long dark period at $2 \mathrm{I}^{\circ} \mathrm{C}$., irrespective of whether this dark period is immediately preceded by a long or a short photoperiod at a relatively low or relatively high temperature. On the other hand, soy bean (I) must be subjected to at least two long dark periods separated by one photoperiod, for the initiation of floral primordia. Evidently the initiation of floral primordia by Xanthium is the result of processes 
taking place during the dark period. Whether or not other species or varieties of plants could be induced to initiate floral primordia during a single dark period under certain conditions of temperature or humidity remains to be determined. It may be that in some plants floral initiation is conditioned by processes taking place during the photoperiod as well as during the dark period.

On the basis of data presented in the foregoing experiments, the behavior of most short day plants and probably also of long day plants and many others can most readily be attributed to the presence of a floral initiating substance whose genesis is probably in the fully expanded leaves when directly exposed to appropriate photoperiods or dark periods. Such substance may be transported throughout the plant.

\section{Summary}

I. A description is given of a simple method whereby one portion of a plant may be subjected to one photoperiod while another portion of the same plant is being subjected to another photoperiod.

2. Floral initiation in Xanthium pennsylvanicum results if plants are subjected to photoperiods shorter than I5 hours with accompanying dark periods of longer than 8 hours. If Xanthium plants are subjected continuously to photoperiods longer than 16 hours with accompanying dark periods shorter than 8 hours they remain strictly vegetative.

3. The initial effect of the photoperiodic stimulus is perceived by the leaves which are subjected to short photoperiod. However, this stimulus, resulting in floral initiation, may be transported from these leaves to other portions of the same plant which are maintained under conditions of long photoperiod and may also move across a diffusion contact from a plant subjected to short photoperiod to a plant subjected to long photoperiod. The stimulus to floral initiation may therefore be attributed to a substance or substances manufactured in leaves subjected to short photoperiod.

4. The response of Xanthium to photoperiod is primarily a response to length of dark period rather than to duration of photoperiod. Thus reactions resulting in the formation of floral initiation 
substances may take place during the dark period. These reactions are adversely affected by light and by low temperature.

5. Fully expanded leaves on receptor branches subjected to long photoperiod may exert some influence inhibitory to floral initiation; under similar circumstances young expanding leaves exert a promotive effect on floral initiation and flower development.

6. In Xanthium the development of mature flowers and fruits from floral primordia is also promoted by a substance or substances formed in portions of the plant which are exposed to short photoperiod and which may move across a diffusion contact. Whether or not this substance or substances is identical with the floral initiation substance has not as yet been determined.

7. A portion of a plant maintained under long photoperiod may be influenced by a portion of the same plant subjected to short photoperiods in such a way that it may behave as though it has been photoperiodically induced by direct exposure to short photoperiod. Flowers and fruits continue to develop on such portions of a branch which has never itself been subjected to short photoperiods.

8. Evidence is presented that the floral initiation substance is not identical with any of the following known plant growth factors: vitamins $B_{1}, B_{2}$, and $B_{6}$, ascorbic acid, nicotinic acid, pantothenic acid, theelin, theelol, inositol, or indoleacetic acid.

University of Chicago

Chicago, Illinois

California Institute of Technology

Pasadena, California

\section{LITERATURE CITED}

I. Borthwick, H. A., and Parker, M. W., Influence of photoperiods upon the differentiation of meristems and the blossoming of Biloxi soy beans. Bот. GAZ. 99:825-839. I 938 .

2. Cajlachjan, M. H., On the mechanism of photoperiodic reaction. Compt. Rend. (Doklady) Acad. Sci. U.R.S.S. I: 89-93. 1936.

3. - On the hormonal theory of plant development. Compt. Rend. (Doklady) Acad. Sci. U.R.S.S. 3:442-447. 1936.

4. Cajlachjan, M. H., and Aleksandrovskaia, V. A., Nature of the photoperiodic after-effect (induction) and effect of day length on the activity of the oxidizing enzymes. Compt. Rend. Acad. Sci. U.R.S.S. $2: 16 \mathrm{I}-166.1935$. 
5. Cajlachjan, M. H., The hormonal theory of plant development. Moscow. I 937 (Russian).

6. Garner, W. W., and Allard, H. A., Effect of the relative length of day and night and other factors of the environment on the growth and reproduction in plants. Jour. Agr. Res. 18:553-606. 1920.

7. Garner, W. W., and Allard, H. A., Localization of the response in plants to relative length of day and night. Jour. Agr. Res. 31:555-567. I925.

8. Garner, W. W., Bacon, C. W., and Allard, H. A., Photoperiodism in relation to hydrogen-ion concentration of the cell sap and the carbohydrate content of the plant. Jour. Agr. Res. 27:119-156. I924.

9. Hamner, K. C., Correlative effects of environmental factors on photoperiodism. Bot. Gaz. 99:615-629. 1938.

го. Knotr, J. E., Effect of a localized photoperiod on spinach. Proc. Amer. Soc. Hort. Sci. 3 I : (suppl.) I 52-I54. I934.

II. KUIJPER, J., and WIERSUM, L. K., Occurrence and transport of a substance causing flowering in the soy bean. Proc. Acad. Sci. Amsterdam 39: II I4II 22. 1936 .

12. Loenwing, W. F., Locus and physiology of photoperiodic perception in plants. Proc. Soc. Exp. Biol. and Med. 37:63I-634. I938.

13. Lubimenko, V., and Bouslova, E., Contribution à la théorie du photopériodisme. II. Compt. Rend. Acad. Sci. U.R.S.S. 14:149-163. 1937.

14. Melchers, G., Die Wirkung von Genen, tiefen Temperaturen und blühenden Pfropfpartnern auf die Blühreife von Hyoscyamus niger L. Biol. Zent. 57:568-6I4. I937.

15. Moshrov, B. S. [Flowering of short-day plants under continuous day as a result of graftingl. Bull. Appl. Bot. Gen. \& Pl. Breed. Ser. A. Supplement. No. 2I. 145-156. 1937.

16. - Role of leaves in photoperiodic reaction of plants. Bull. Appl. Bot. Gen. \& Pl. Breed. Ser. A. 17:25-30. 1936.

17. SACHS, J., Gesammelte Abhandlungen über Pflanzen-physiologie. Leipzig. I: 229-260. I892; 2: I 168-II70. I893.

I8. Shive, J. W., A three-salt nutrient solution for plants. Amer. Jour. Bot. 2:157-160. I915. 